\title{
OBJECTIVE AUDIOMETRY IN INFANTS: ELECTROCOCHLEOGRAPHY AND BRAIN STEM RESPONSE
}

\section{TADAHIKO INO}

\author{
Department of Otolaryngology, Faculty of Medicine, Keio University, Tokyo \\ (Director: S. Saito, M.D.)
}

A total of 70 infants, complaining of hearing loss or speech retardation, were employed in this study. Evoked Response Audiometry (ERA) was carried out for 63 infants, Electrocochleography (ECoG) for 26 infants and Brain Stem Response (BSR) for 41 infants. The role of these objective audiological examinations in ped-audiology was evaluated.

The results were as follows:

1) ERA is the best method to judge whether the infant is total deaf or not.

2) Response thresholds of electrocochleographical AP and BSR were lower than those of ERA.

3) Thresholds of AP responses to tone pips of $2 \mathrm{kHz}, 4 \mathrm{kHz}$ and $8 \mathrm{kHz}$ were in relatively good agreement with the behavioral hearing thresholds for pure tones of each frequency.

4) Response threshold of BSR to click was generally in good agreement with the subjective threshold for the same stimuli. In case of sharp-cut type high tone hearing loss (above $2 \mathrm{kHz}$ ), however, there was a great difference between them.

5) Latencies of AP in infants differ from those in adults.

6) Since standard deviations of BSR-latency were much greater than those of AP-latency, the measurement of BSR latency is not useful in differential diagnosis of hearing losses.

$79 \mathrm{~A}-0891.23522$

\section{幼児の他覚的聴力検査の検討}

— 蝸電図, 聴性脳幹反応について—

\section{慶応義秏大学医学部耳楐咽喉科学教室（主任：斎藤成司教授）}

猪忠彦

\section{I 腥 言}

難聴が疑われる幼坚の衈力検查は，言語獲得の可能性 を判断する上飞極めて重大である．乳奻児に対する聴力 检查は従来上り種々あるが，聴力の正確な測定は不可能 であった. 近年新らしい他賞的聼力検查法として, 螖電 因 (聴神経複合活動電位の記録) 户聴性脳幹反応 (以下 BSR と省略) の記録が行われる様になって来た. 他方, 幼坚の他賞的検查法として誘発反応聴力检查 (ERA) が 行われてきていたが, 麻醉深度の問題, 反応波形の判定 の難かしさなどがあって，患児の「きこ元」の状態を適
確に把握できなかった，私甠今回，螖笔图法， BSR K ついて検討を加え，末梢レベルての恥袹経系の活動状態 を检討してきた。これらの新らしい㭘查法が，彷来より 行われている ERA と買なって，どの様な意義を持って いるのかを検討した。

$$
\text { II 方法 }
$$

1. 梌查対象

昭和 48 年 9 月上り昭和50年 2 月までの間に，慶灾義坥 大学病院耳鼻咽喉科外来汇難衈を主訴として来院した患 児 70 名で方る，年令㑐㩆少 4 ケ月より最長 9 才 8 ケ月 


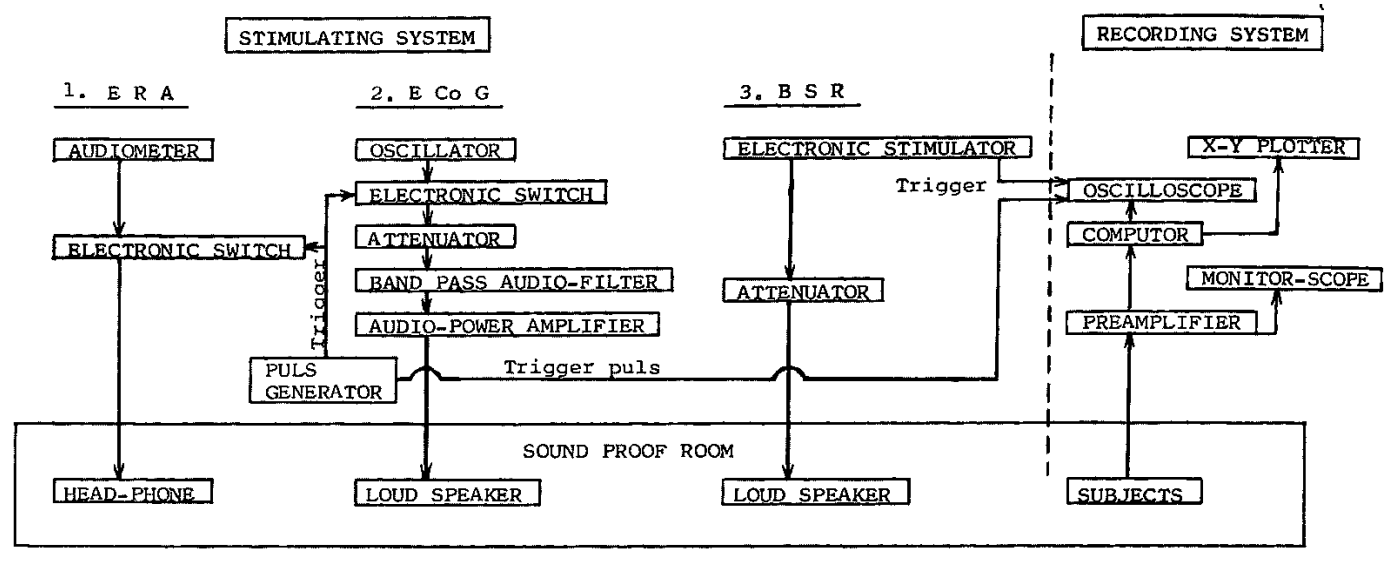

图 1 検查装置のブロックダイアグラム

で, 平均年令は 2 才10ケ月である.

2. 誘発反応聴力榆查 (ERA)

検查装置: 図1のブロックダイアグラムK示す通り である. Audiometer (Rion, AA-34)，電子スイッチ (Rion, SB 01 A), 脳波增幅器 (三栄), 平均加算器 (三 栄, Mediac MC 401), 記録装置 (理研, D-73) であ る.

刺激音: $500 \mathrm{~Hz}, 1 \mathrm{kHz}, 2 \mathrm{kHz}, 4 \mathrm{kHz}, 8 \mathrm{kHz}$ の Tone

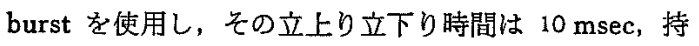
続時間は $100 \mathrm{msec}$ ，刺激間隔は 4 秒である。検查音は 強い音加ら $10 \mathrm{~dB} \sim 20 \mathrm{~dB}$ ずつ漸減した。

記録: (十) 電極を頭頂部，(）電極を耳垂，アース 電極を前額鼻根部として差動增幅し，加算回数は60回々 し，20回每《加算波形を観察記録した．分析時間は 2 秒 である.

麻酔: トリクロリールシロッププ $90 \mathrm{mg} / \mathrm{kg}$ 内服後, 30〜 45分様子を見て睡眠しなければ, コントミン $0.5 \sim$ $1 \mathrm{mg} / \mathrm{kg}$ 筋注を行う.これでも眠らない時恬，後日薬 用量を变更して再度施行した。

検查対象：対象患児70名中の63名に ERA を行った。

判定：誘発反応の遅い成分を指標とした. 反応波形の 基準として $500 \mathrm{~Hz} 90 \mathrm{~dB}$ の音で, guide pattern をと $b^{26)}$ ，各刺激の反応飞ついて検討した。 20 回加算待沉記 録を行い，加算により成長して行く過程を観祭した。な 招各周波数，各音化について検査するには 2 洔間位を要 し，その間渪眠澡度を一定に保つのは不 可能であった 5).

\section{3. 蝸電図 (ECoG)}

検查装置：図1Kブロックダイアグラムを示す 発振
器 (Hewlett-Packard 社 $434 \mathrm{Y}$ ), 霆子スイッチ (Rion, SB-03), 減衰器 (安藤, AL-205), Audiofilter (Rion, SA 2701 B 型), パワーアンプ (SONY, TA 1000), スピーカー（サンス1，SP-25）飞て刺激系統を作り， 前置增幅器 (日本光雪, RB-5), Oscilloscope (日本光 電, $\mathrm{VC}-7$ ), 平均加算器 (日本光電, ATAC 401), XY Recorder (理研, F-3 B) 飞て記録系統は粠成されて いる.

刺激音: 螖牛神経複合活動雷位 (AP) の記録に際して は， $2 \mathrm{kHz} ， 4 \mathrm{kHz} ， 8 \mathrm{kHz}$ の tone pip を用いた ${ }^{24) 50 \%}$ それぞれの音の条件については表 1 亿示した。音の間隔 は $150 \mathrm{msec} と し た{ }^{49}$.

記録: 鼓室内誘道法飞て行った. $(+)$ 電極として 80 $\mu$ のステンレススチールを用い，固定には生体用接着剤 （三共，アロンアルファ）を使用した。 な拓接地抵抗肪 $100 \mathrm{k} \Omega$ 以下となる時のみ誘道を行った.（一）電極とし て耳垂に血電極を，ア一ス電極を前額部倿着した. 加

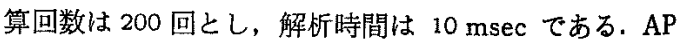
記録時《は，蝸牛マイクロフォン電位が消去される様に random phase の立上りを持つ音を用いた ${ }^{511}$.

麻醉：誘発反応德力検查を終えて觉醒の状照になった 患児に点滴静注を行うとともにケタラール $3 \sim 5 \mathrm{mg} / \mathrm{kg}$

表 1 螖電図刺激音（Tone pip）の条件

\begin{tabular}{c|c|l|c}
\hline 周波数 & 立上り立り時間 & 持続時間 & 沪波 帯 域 \\
\hline $8 \mathrm{kHz}$ & $1 \mathrm{msec}$ & $3 \mathrm{msec}$ & $6,800 \sim 9,600 \mathrm{~Hz}$ \\
$4 \mathrm{kHz}$ & $1 \mathrm{msec}$ & $3.5 \mathrm{msec}$ & $3,400 \sim 4,800 \mathrm{~Hz}$ \\
$2 \mathrm{kHz}$ & $1 \mathrm{msec}$ & $3.5 \mathrm{msec}$ & $1,700 \sim 2,400 \mathrm{~Hz}$ \\
\hline
\end{tabular}


筋注を行 ${ }^{1754)} .15 \sim 20$ 分後に針電極を経鼓膜的に鼓室 岬角に固定した。

検查対象：70名の患児中26名に施行した.

判定: AP 反応の域值, 潜時, 振幅, 波形飞ついて检 討した。

\section{4. 聴性脳幹反応 (BSR)}

榆査装置：図1にブロックダイアグラムを示す.クリ ック用パルス発生器 (日本光電, 電子管刺激装置 MSE$3 \mathrm{R}$ ), 減衰器 (安藤, $\mathrm{AL} 205$ 型), パワーアンプ(ソニ 一, TA 1000)，スピーカー(サンス1，SP-25) を用い た. 記録系装置は蝸電図と全く同一である。

制激音: 持続 $0.1 \mathrm{msec}$ の矩形波を $4,800 \sim 9,600 \mathrm{~Hz}$

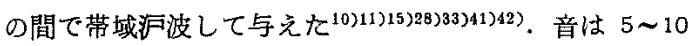
$\mathrm{dB}$ ステップで与え，正常人の可聴域值を $0 \mathrm{~dB}$ として 音の强さを示した．この場合， $0 \mathrm{~dB}$ から $70 \mathrm{~dB}$ までは ほほ直線的振幅増加があるが，これ以上音圧をあげる と，音が飽和したので使用しなかった，音刺激の間隔は $125 \mathrm{msec}$ とした ${ }^{1433) 46)}$.

記録：血電極を用い，頭頂，耳垂間で誘導した．加算 回数は 2,000回, 分析時間は $25 \mathrm{msec}$ とした. 增幅器 の周波数带域は $10 \mathrm{~Hz} \sim 1 \mathrm{kHz}(12 \mathrm{~dB} / \mathrm{Oct})$ とした。 螖牛マククロホン電位を消去するために Condensation click と Rarefaction click とを同数加算した.

床酔: ERA の場合と全く同じでちる。

険查詨象: 70 名中41名に施行した.

判定：聴性脳幹反応群 $\left(W_{1} \sim W_{5}\right)$ のうち, $W_{1} と W_{5}$ について潜時, 域値などを検討した。

5. その他の検查法

条件詮卖反応検查法 (COR) は 70 名中 30 名行った 加, COR-Box (永島, S-1), Audiometer (Rion, AA -34）を使用した.

聴性行動反応検查は部屋の四隅に置いたスピーカーよ り白色雑音 (A 特性 98 phone) を与光て行い，70名中 43 名飞施行した。

\section{III結 果 一螖電図一}

螖電困を施行したのは26名である。これら26名の患児 の聴力像は，他の検查結果をも考慮すると表 2 の様份分 類できた，すなわち聴力ほほ正常の者 7 名，高音渐傾型 で比較的水平型の者 6 名, 高音急壁型で高音で scale out を示す者 6 名，低音部にのみ残聴のある者 2 名，全ての 音仅反応なし 5 名である。

1. 反応の有無 -ERA と螖電図の比較一

舧電図に括ける AP 反応の有無と ERA ての反応の
表 2 螖電図施行例 (26名) の聴力

\begin{tabular}{cccc||l}
\hline ほ & ほ & 正 & 常 & 7 名 \\
高 & 音 & 溸 & 傾 & 6 名 \\
高 & 音 & Scale out & 6 名 \\
低 & 音 & 残 & 聴 & 2 名 \\
全 & 音 & Scale out & 5 名 \\
\hline
\end{tabular}

表 3 ERA 及び蜘電困 (AP) の反応検出率

\begin{tabular}{|c|c|c|c|}
\hline & 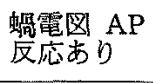 & $\begin{array}{l}\text { 螖電浔 AP } \\
\text { 反灾なし }\end{array}$ & \\
\hline ERA 反応あり & 16名 & 7名 & $88 \%$ \\
\hline \multirow[t]{2}{*}{ ERA 反応なし } & 1名 & 2名 & $12 \%$ \\
\hline & $65 \%$ & $35 \%$ & \\
\hline
\end{tabular}

有無を検討した.しかしこの二つの検査法は，それぞれ が报う刺激音の周波数や最大音生，音波形など飞於て相

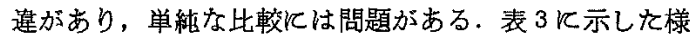
に反応検出率では ERA の方がはるが高い，すなわち 螖電图施行者26名の中で AP 反応を認めなかった者が9 名あり，その内の 7 名は ERA で反応を認めた. 他方， 蛤電図 AP 反応加得られた飞す拘らず ERAで応の得 られなかったのは1例炕ずない。しかるこの1例は， ケタラール麻酔下K ERA を施行せざるを得なかった唯 一の例で，背景脳波が小振幅の速波で反応検出の条件亡 して不適当な点があったと考えられる例であった，

\section{2. 反応域值}

图 $2 k ， 2 \mathrm{kHz} ４ \mathrm{kHz}, 8 \mathrm{kHz}$ の各刺激音飞対士る的 電図の反応域值と，ERAの反応域值との関係を示した。 ERA の反芯域值は最も低いものでも30 dB であるのに

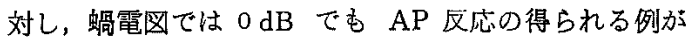
ある.四2 亿示された各点は大部分が斜線より上方机 って，反応が得られれば螖電図 AP の反応域值の方が 低いことになる.ERA，蝸笔図の雨方に反応の得られた 例飞ついて，ERA 反心域侹と蝸電図 AP反応域値との 差が各刺激音によりどの様になるかを示したのが表 4で

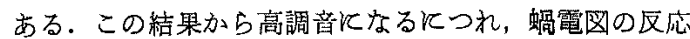

表 4 ERA 反応域值と蝸電図 AP 反応域值との差

\begin{tabular}{c|c|c|c}
\hline 刺激音 & 例数 & 反応域值の差 (平均) & 標準偏差 \\
\hline $8 \mathrm{kHz}$ & 10 & $40 \mathrm{~dB}$ & $19.9 \mathrm{~dB}$ \\
$4 \mathrm{kHz}$ & 16 & $26.6 \mathrm{~dB}$ & $21.3 \mathrm{~dB}$ \\
$2 \mathrm{kHz}$ & 6 & $18.3 \mathrm{~dB}$ & $16.0 \mathrm{~dB}$ \\
\hline
\end{tabular}




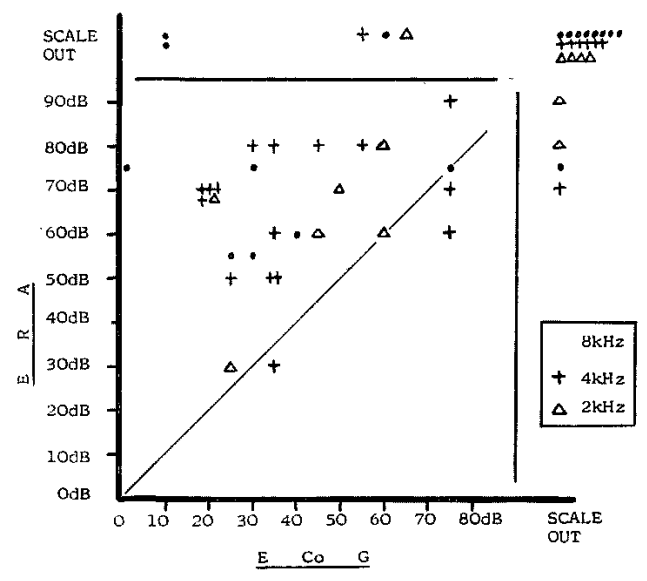

図 2 ERA と螎電図 AP の反応域值 横軸は tone pip を刺激音とした蝸電図 AP 反応域 值を示し，絴軸は tone burstを刺激音とした ERA 反応域值を示す，一印は $8 \mathrm{kHz}$ の刺激音, 十印は 4 $\mathrm{kHz}$ の刺激音, $\triangle$ 印は $2 \mathrm{kHz}$ の刺激音に対する反 応域值を示す

表 5 純音聴力域值と蝸電図 AP 反応域値との差 (成人突発難聴例)

\begin{tabular}{c|c|c|c}
\hline 音 & 例数 & $\begin{array}{c}\text { 純竟聴力域值之反度 } \\
\text { 域值 差(墂準偏差 }\end{array}$ \\
\hline $8 \mathrm{kHz}$ & 15 & $2.7 \mathrm{~dB}$ & $6.29 \mathrm{~dB}$ \\
$4 \mathrm{kHz}$ & 17 & $2.9 \mathrm{~dB}$ & $8.24 \mathrm{~dB}$ \\
$2 \mathrm{kHz}$ & 12 & $8.3 \mathrm{~dB}$ & $9.86 \mathrm{~dB}$ \\
\hline
\end{tabular}

がより得られやすい倾向があると言える。

図 3 Kは, 突発難㯖の成人で純音鿵力検査と螖電図を 行った者の, 純音恥力損失值と蝸電図 AP 反応域值との 関係を示した，表 5 には，突発難恥の成人の純音徳力損 失值と螖電図 AP 反応域值との差を検討した結果が示さ れている. $2 \mathrm{kHz}, 4 \mathrm{kHz}, 8 \mathrm{kHz}$ の差の平均を相互に

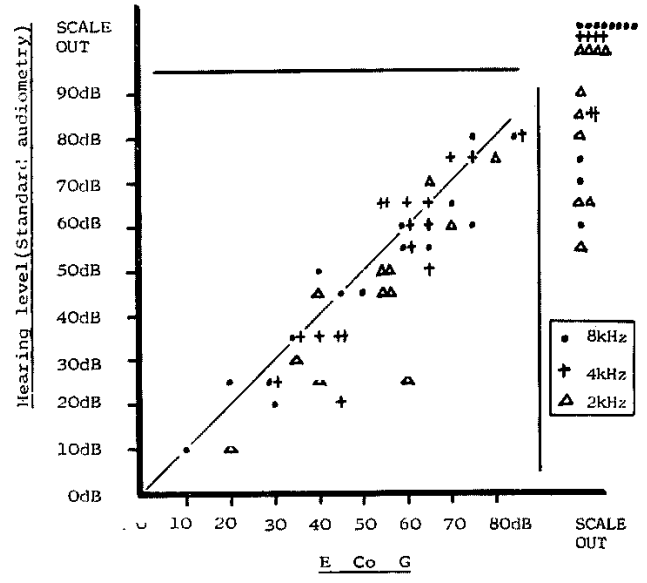

図 3 蝸電図 AP 反芯域值之純音德力損失值（突発 難聴成人に晾ける資料)

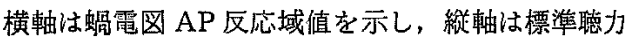
検查飞於ける聴力損失值を示す。印は $8 \mathrm{kHz}$ tone pip の刺激音注対する AP 反応域値と $8 \mathrm{kHz}$ 維音

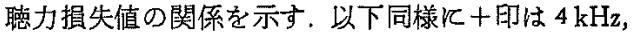

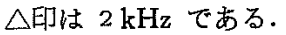

桧定したが，いずれも有意の差ではなかった．従って 2 $\mathrm{kHz} \sim 8 \mathrm{kHz}$ の高調音については, 蝸電図 AP 反応域 值と純音自觉域值とは比较的近い值をとる傾向があると 言光る.

3. 反応潜時

潜時とは，音のはじまりから AP反応のピークまでの 時間である，音のはじまりとは，鼓膜の位置（外耳孔ま での距離 $+3 \mathrm{~cm}$ ) の所徝いたマイクロホンより記録 された望波形のはじまりである。表 6 K $8 \mathrm{kHz}$ tone pip に対する蝸電図 AP 反応の潜時を示した. 聴力正常児群 と難徳児群とにわけて，潜時の平均，標準偏差を求めた。 この二群の間には有意の差加見当らなかった，この表に

表 $68 \mathrm{kHz}$ Tone pip 飞封する蝸電図 AP 反応潜時

\begin{tabular}{|c|c|c|c|c|c|c|c|c|c|c|c|}
\hline \multirow{2}{*}{ 音の強さ } & \multicolumn{3}{|c|}{ 恥 力 正 常 児 } & \multicolumn{2}{|c|}{ 難 } & \multirow{2}{*}{$\begin{array}{l}\text { 聴 } \\
\text { 時 } \\
\text { 均 } \\
\end{array}$} & \multirow{2}{*}{ 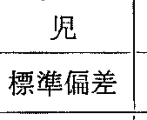 } & \multicolumn{3}{|c|}{ 突 発 難 聴 成人 } & \multirow{2}{*}{ 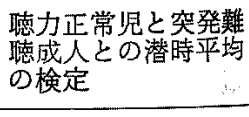 } \\
\hline & 例数 & $\begin{array}{cc}\text { 潜 } & \text { 時 } \\
\text { 平 均 } \\
\end{array}$ & 標準偏差 & 例数 & $\frac{\text { 潜 }}{\text { 怣 }}$ & & & 例数 & $\begin{array}{ll}\text { 潜 眯 } \\
\text { 羊 均 } \\
\end{array}$ & 標準偏差 & \\
\hline $80 \mathrm{~dB}$ & 7 & \multicolumn{2}{|c|}{$1.8 \mathrm{msec} 0.096 \mathrm{msec}$} & 7 & \multicolumn{2}{|c|}{$1.8 \mathrm{msec}$} & $0.18 \mathrm{msec}$ & 8 & $1.6 \mathrm{msec}$ & $0.19 \mathrm{msec}$ & \multirow{2}{*}{$\begin{array}{c}\text { 10\%て有意 } \\
\text { - }\end{array}$} \\
\hline 70 & 7 & 2.0 & 0.096 & 6 & 2.1 & & 0.17 & 8 & 1.85 & 0.28 & \\
\hline 60 & 7 & 2.3 & 0.12 & 6 & 2.3 & & 0.17 & 7 & 2.1 & 0.16 & 5\%で有意 \\
\hline 50 & 7 & 2.6 & 0.13 & 5 & 2.6 & & 0.12 & 6 & 2.5 & 0.16 & 5\%で有意 \\
\hline 40 & 7 & 2.85 & 0.19 & 5 & 3.0 & & 0.17 & 6 & 2.85 & 0.11 & $-\quad$ \\
\hline 30 & 7 & 3,2 & 0.25 & 5 & 3.4 & & 0.44 & 3 & 3.2 & 0.12 & - \\
\hline 20 & 7 & 3.5 & 0.325 & - & 一 & & - & - & - & - & 一 \\
\hline
\end{tabular}




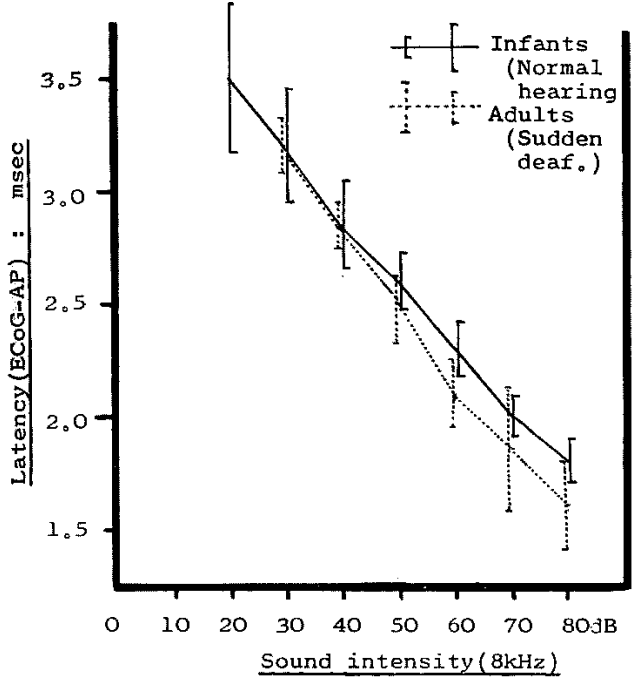

図 $48 \mathrm{kHz}$ tone pip K対する蝸電図 AP 反応の 潜時

横軸は刺激音の強さを示し，緃萁は潜伏時間を示す。

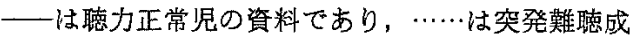
人の資料である。絴に描いた線は標準栾差を示す。

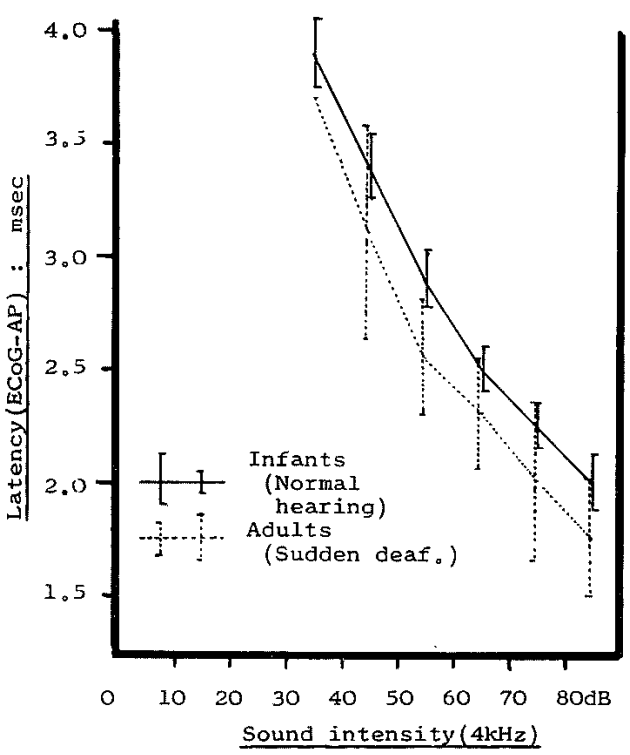

図 $54 \mathrm{kHz}$ tone pip 飞対する蛨電图 AP 反応の 潜時

横軸は刺激音の強され示し，絴軸は潜伏時間を示す 一は聴力正常児の資料であり，…は突発難聴成 人の凟料である.縦にひいた線は標準偏差を示す

表 $74 \mathrm{kHz}$ Tone pip 飞対する螖電図 AP 反応潜時

\begin{tabular}{|c|c|c|c|c|c|c|c|c|c|}
\hline \multirow{2}{*}{ 音の強さ } & 聴 & j 正 & 常 児 & \multicolumn{2}{|c|}{ 傕 } & 垷 & \multicolumn{2}{|c|}{ 突 発 難 聴成人 } & \multirow{2}{*}{ 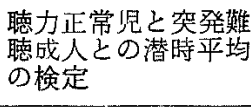 } \\
\hline & 例数 & $\begin{array}{ll}\text { 替 } & \text { 時 } \\
\text { 平 均 }\end{array}$ & 標準偏差 & 例数 & $\begin{array}{l}\text { 潜 時 } \\
\text { 平 均 }\end{array}$ & 標準㨝差 & 例数 潜 時 & 標準倨差 & \\
\hline $85 \mathrm{~dB}$ & 5 & $2.0 \mathrm{msec}$ & $0.13 \mathrm{msec}$ & 8 & $1.9 \mathrm{msec}$ & $0.27 \mathrm{msec}$ & $131.75 \mathrm{msec}$ & $0.27 \mathrm{msec}$ & 10\%で有意 \\
\hline 75 & 5 & 2.25 & 0.10 & 7 & 2.2 & 0.33 & 132.0 & 0.36 & 25\%で有意 \\
\hline 65 & 5 & 2.5 & 0.11 & 6 & 2.6 & 0.38 & 112.3 & 0.24 & 25\%で有息 \\
\hline 55 & 5 & 2.9 & 0.13 & 6 & 2.95 & 0.49 & 102.55 & 0.27 & 5\%で有意 \\
\hline 45 & 5 & 3.4 & 0.14 & 5 & 3.2 & 0.57 & 73.1 & 0.47 & 25\%で有意 \\
\hline 35 & 5 & 3.9 & 0.16 & 5 & 3.8 & 0.64 & 33.7 & 0.41 & - \\
\hline
\end{tabular}

は，対照として成人の突発難聴者の資料を入れてある が，これは正常者に螖電図を行い得なかったこと，及び 感音難聴では潜時に変化が出現しないと言われているか らである．この聴力正常児と突発難聴成人の潜時につい て検定を行うと有意の差を示している.この結果は四 4 に示した. $4 \mathrm{kHz}$ tone pip 住する螖電图 AP 反応の 潜時については，表 7 . 図 5 亿示したが，聴力正常児之 架発難聴成人との差は一層明白になっている。

4. AP 反応の振幅

AP 振幅は，潜時にくらへ「バラッキ」の大さい指標 である，鼓室内誘道法に於ける AP 振幅は，強音では素
表 8 強音 $(85 \sim 80 \mathrm{~dB})$ に対する蝸笔図 $\mathrm{AP}$ 反応の振巾

\begin{tabular}{|c|c|c|c|}
\hline & 例 数 & $\mathrm{AP}$ 振巾 (平比) & 標瞋编差 \\
\hline 聴力正常児 & 14 & $46.88 \mu \mathrm{V}$ & $29.9 \mu \mathrm{V}$ \\
\hline 嚄 聴 览 & 13 & $8.97 \mu \mathrm{V}$ & $7.19 \mu \mathrm{V}$ \\
\hline
\end{tabular}

8 K示寸様に，聴力正常览では $8.63 \mu \mathrm{V} \sim 93.5 \mu \mathrm{V}$ の間 飞あり, その平均は $46.9 \mu \mathrm{V}$, 標泳偏差は $21.9 \mu \mathrm{V}(\mathrm{N}$ =14）であった，他方，難㯖児では $1.94 \mu \mathrm{V} \sim 25.6 \mu \mathrm{V}$ の間で，その平均は $8.97 \mu \mathrm{V}$ ，標準偏差は $7.19 \mu \mathrm{V}(\mathrm{N}$ =13）であった。この二群の標準偏差を校定すると $1 \%$ 
で有意な為，母平均の検定は不可能であるが，難聴児の 方が振幅が小さいことは明白である。

$\mathrm{AP}$ 振幅と音の強さの関係をパターンとしてとら光る 飞は， AP 振幅を $\mu \mathrm{V}$ で表示するより，各人の最大振 幅を $100 \%$ としてそれ《対する割合で AP 振幅を表示 する\% Maximum の方式が，見かけ上「バラッキ」が 少なく解り易い，図6亿は聴力正常児の AP 振幅の灭均 （\% Maximum） と音の強さとの関係が示してあるが, $8 \mathrm{kHz}$ の方では $\mathrm{H}$ 曲線と $\mathrm{L}$ 曲線 ${ }^{50)}$ の変曲点が明確で はないが， $4 \mathrm{kHz}$ 刺激音では中等度音王飞於て变曲点が ある様見える. $8 \mathrm{kHz}$ と $4 \mathrm{kHz}$ とのこの様なちがい を招こす原因は不明である.表 9 飞は聴力正常児の数值 を示したが，難聴児については表10反示した，な招，難 聴児では例数が少なく偏差が大きいので，最小値と最大 值の幅を示した。

5. AP 反応波形の $\mathrm{L}$ 反応飞ついて

し 反応とは，弱い音飞対する AP 反応のことである，

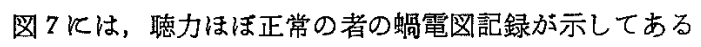
が， $45 \mathrm{~dB}$ 以下の弱音の時飞見られる L 反応は， $65 \mathrm{~dB}$ 以上の強音の時には抑制されてしまっている.幼児的電

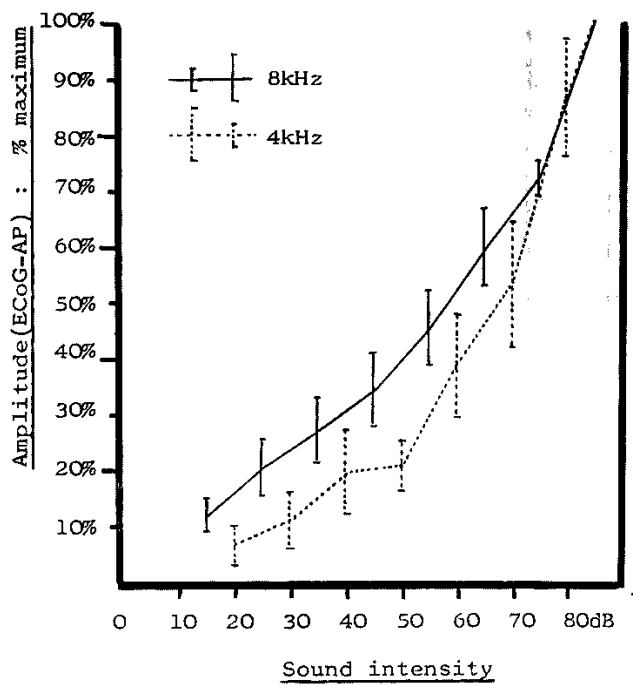

図 6 蝸電図 AP 反応の振幅音王曲楾（聴力正常児 の資料)

横軸は刺激音の強さを示し, 縦軸は AP 振幅を \% Ma ximum で示したものである.—— $8 \mathrm{kHz}$ の刺激音に 対する $\mathrm{AP}$ 振幅を示し， $\cdots \cdots$ は $4 \mathrm{kHz}$ 刺激音比対する 振幅を示す. 縦にひいた線は標準偏差である。

表 9 蟙電困 AP の振市（\% Maximum）（聴力正常児）

\begin{tabular}{|c|c|c|c|c|c|c|c|c|c|c|c|}
\hline \multicolumn{6}{|c|}{$8 \mathrm{kHz}$} & \multicolumn{6}{|c|}{$4 \mathrm{kHz}$} \\
\hline 音 & の強さ & 例 & 数 & 振巾平均 & 標準偏差 & & の强さ & 例 & 数 & 振巾平均 & 標準偏差 \\
\hline & $85 \mathrm{~dB}$ & & & $100 \%$ & 0 & & $85 \mathrm{~dB}$ & 5 & & $100 \%$ & 0 \\
\hline & $75 \mathrm{~dB}$ & & & 72.1 & $3.25 \%$ & & $80 \mathrm{~dB}$ & 6 & & 86.8 & $10.61 \%$ \\
\hline & $65 \mathrm{~dB}$ & & & 59.3 & 6.58 & & $70 \mathrm{~dB}$ & 5 & & 53.1 & 11.19 \\
\hline & $55 \mathrm{~dB}$ & & & 45.2 & 6.87 & & $60 \mathrm{~dB}$ & 6 & & 38.8 & 9.04 \\
\hline & $45 \mathrm{~dB}$ & & & 34.2 & 6.63 & & $50 \mathrm{~dB}$ & 6 & & 20.5 & 4. 50 \\
\hline & $35 \mathrm{~dB}$ & & & 27.0 & 5.99 & & $40 \mathrm{~dB}$ & 6 & & 19.0 & 8.05 \\
\hline & $25 \mathrm{~dB}$ & & & 20.2 & 5.03 & & $30 \mathrm{~dB}$ & 6 & & 10.8 & 5.11 \\
\hline & $15 \mathrm{~dB}$ & & & 11.9 & 3.02 & & $20 \mathrm{~dB}$ & 4 & & 6.5 & 3.61 \\
\hline
\end{tabular}

表10 蝸電図 AP の振巾（\% Maximum）(難聴児)

\begin{tabular}{|c|c|c|c|c|c|c|c|c|c|c|c|}
\hline \multicolumn{6}{|c|}{$8 \mathrm{kHz}$} & \multicolumn{6}{|c|}{$4 \mathrm{kHz}$} \\
\hline 音 & の強さ & 例 & 数 & 最 小值 & 最大值 & 音 & の強さ & 例 & 数 & 最小値 & 最大値 \\
\hline & $85 \mathrm{~dB}$ & & & $100 \%$ & & & $85 \mathrm{~dB}$ & & & $100 \%$ & \\
\hline & $80 \mathrm{~dB}$ & & & 75.0 & $100 \%$ & & $75 \mathrm{~dB}$ & & & 43.3 & $88.9 \%$ \\
\hline & $70 \mathrm{~dB}$ & & & 69.4 & 100 & & $65 \mathrm{~dB}$ & & & 32.1 & 88.9 \\
\hline & $60 \mathrm{~dB}$ & & & 55.7 & 89.5 & & $55 \mathrm{~dB}$ & & & 19.5 & 66.7 \\
\hline & $50 \mathrm{~dB}$ & & & 36.8 & 68.4 & & $45 \mathrm{~dB}$ & & & 12.2 & 44.4 \\
\hline & $40 \mathrm{~dB}$ & & & 26.7 & 52.6 & & $35 \mathrm{~dB}$ & & & 4.9 & 33.3 \\
\hline & $30 \mathrm{~dB}$ & & & 6.7 & 21.0 & & & & & & \\
\hline
\end{tabular}




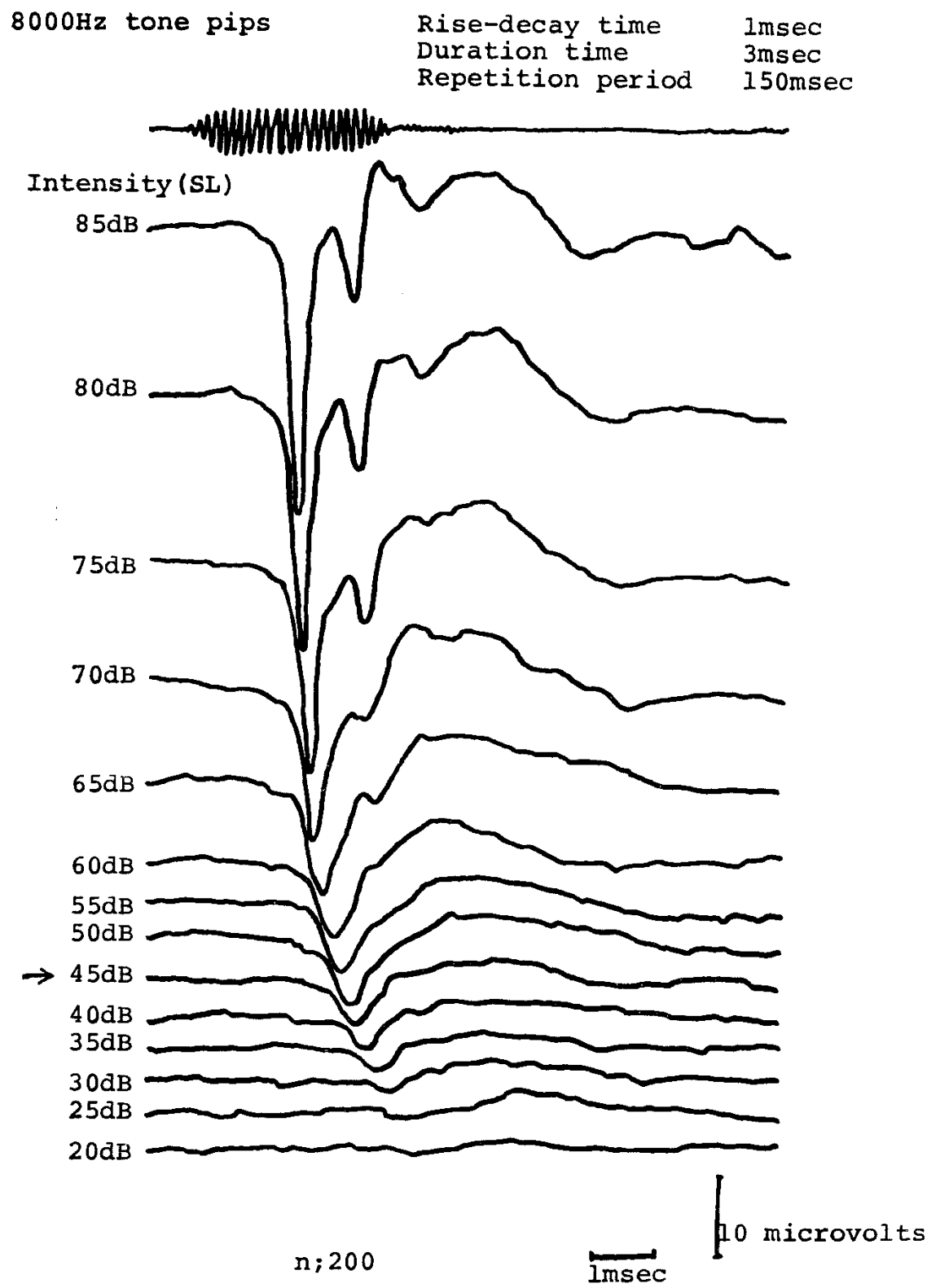

図 7 㯰力正常者の螖電図記録

$45 \mathrm{~dB}$ 以下で見られる $\mathrm{L}$ 反応は， $65 \mathrm{~dB}$ 以上の刺激音では消失している.

図施行例の中に，強音飞於ても L 反応が残っていて， $\mathrm{H}$ 反応任重なって認められた例があった．四8は，その 様な $\mathrm{H}$ 反応と L反応が重なった二峯性の波が認められ た 2 才10ケ月の患児の螖電図記録である．この患児は歩 行閏始が遅く，遠域寺式乳奻児分析的発達質問表か 5 情 意発達・知的発達・社会的発達にも遲れがあり, 神経系
の広沉な障害の存在を疑わせた例である。

6. SP 滕電位について

AP より早く出現し，刺激音の持続時間と同じ長さを 示す值流電位変動を SP と呼ぶ. 図 7 の正常螖電図では この様な笔位袈動はない，図 9 は聴力正常児ではあるが $+\mathrm{SP}$ を示した例である.この様な $+\mathrm{SP}$ を示したもの 


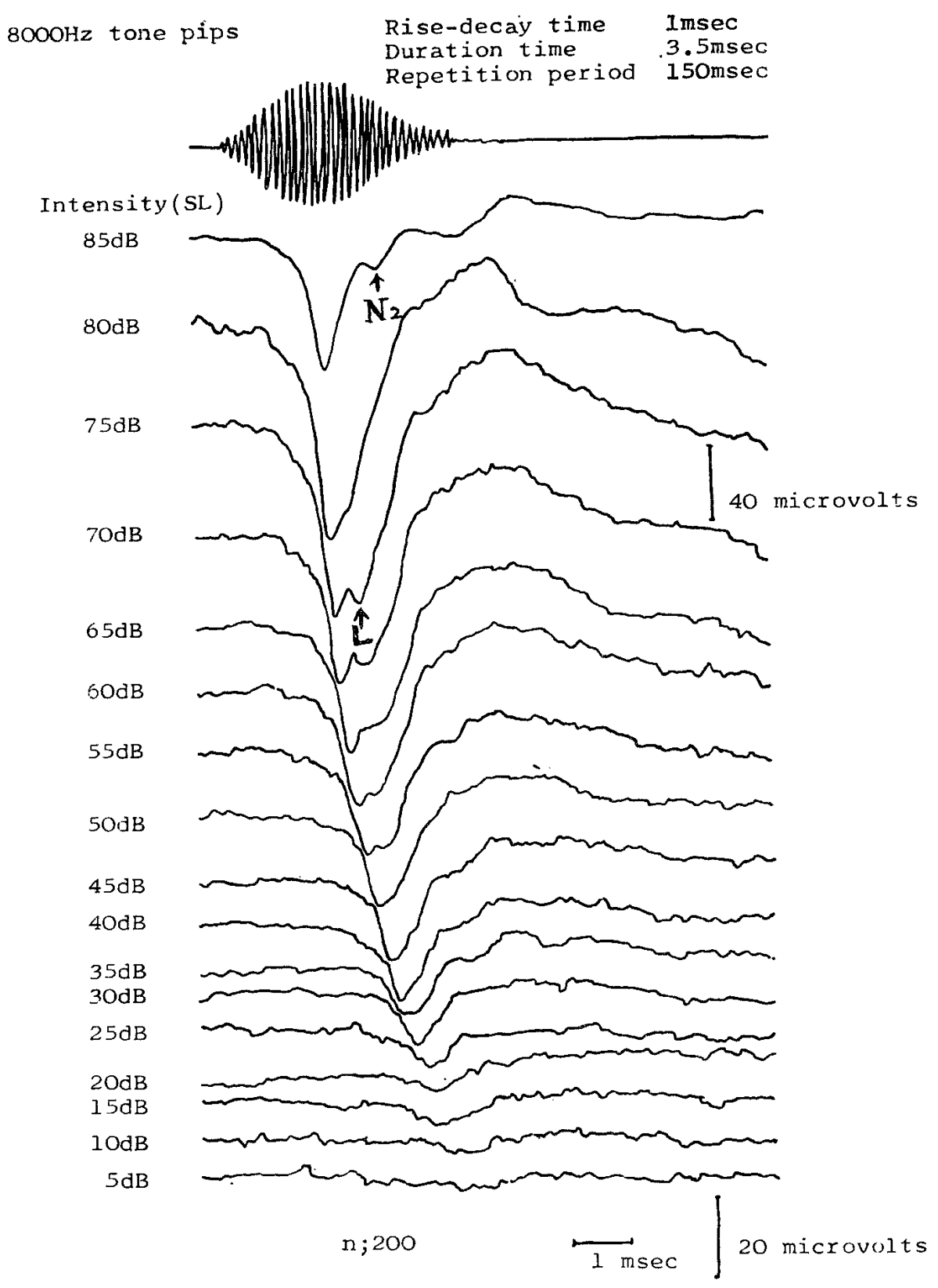

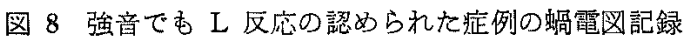

は二児であり、いずれあ $8 \mathrm{kHz}$ の强音に於てのみであ

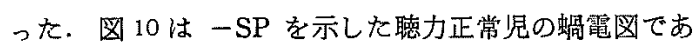
る.この様な $-\mathrm{SP} 4 \mathrm{kHz}$ の強音炕対してはしばし ば認められる。

$$
\text { IV 考 察 一蝸電図一 }
$$

\section{1. 反态の有無}

蝸電図で AP 反応がとれるのは，刺激音が $1 \mathrm{kHz}$ 以 上の高調音の時のみである ${ }^{50)}$. 特飞我々の注目している $\mathrm{AP}$ 反応は，螖牛の主として基底回転の反心であって， 蝸牛尖端部の反応は travelling-time delay Kよりうま 

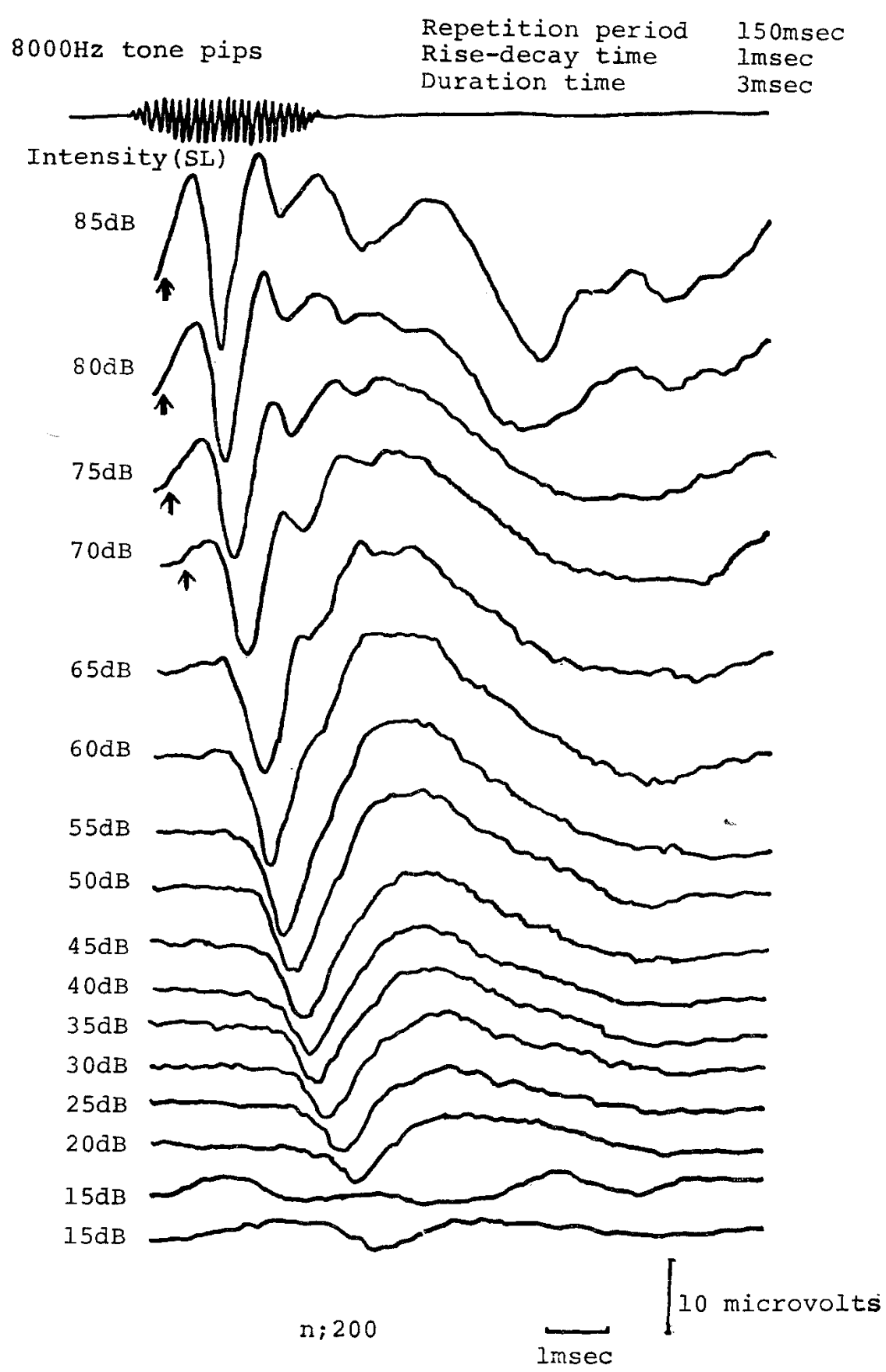

図 $9+\mathrm{SP}$ 方記録された提例の螖霓図記録

$70 \mathrm{~dB}$ 以上の音で +SP が認められる（＼cjkstart印で示し沈所よりはじまる） 


$\begin{array}{lll}4000 \mathrm{~Hz} \text { tone pips } & \begin{array}{l}\text { Rise-decay time } \\ \text { Duration time }\end{array} & 3.5 \mathrm{msec} \\ \text { Repetition period } & 150 \mathrm{msec}\end{array}$

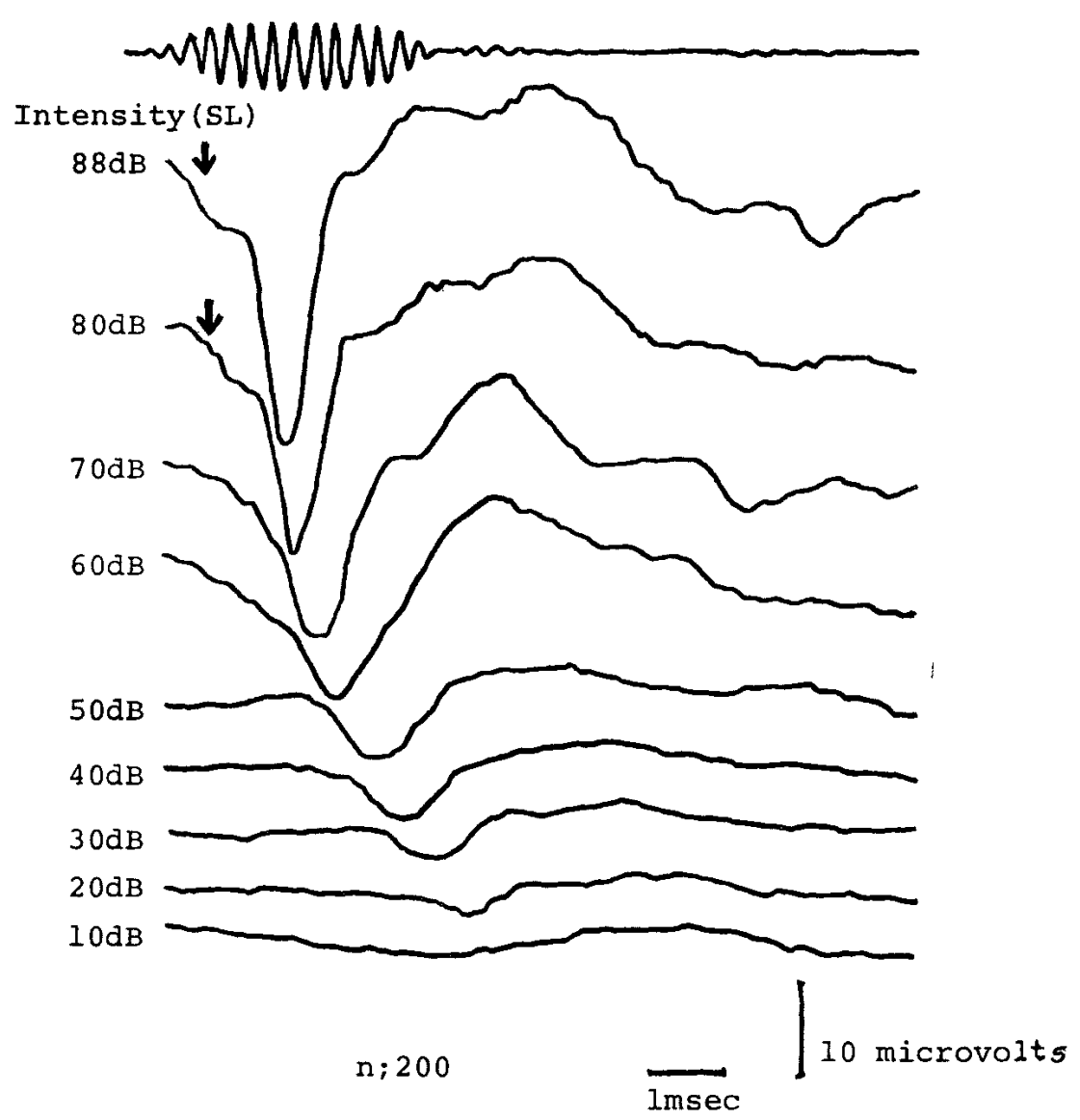

図10-SP が記録された症例の的骨電図記録

$80 \mathrm{~dB}$ 及び $88 \mathrm{~dB}$ の強い音で - SP( $\uparrow$ 印で示した) が認められる.

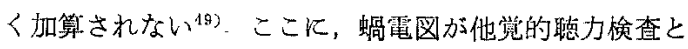
して限界を持つ原因がある。他方，ERAは種々の周波 数の Tone burst を用いて特り, 特飞 $500 \mathrm{~Hz}, 1 \mathrm{kHz}$

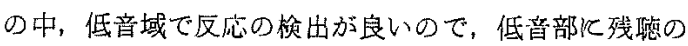

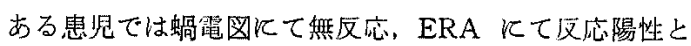
なることが度々認められる。

螖電図のこの様な久点を補うために低音部については 螖牛マイクロホン電位 (CM) 指㯲として検討してい るが，実際には CM は周波数の情報を与えないしか， Artifact と CM を区別する方法がない，なとの久点が ある. 以上の様な欠点を持ちながらな和かつ他党的聴力 㛟查として螖電図を行うのは，ERAと比較して(1)時間
がかからない(2)再現性がある(3)睡眠深度の影響を受けな い(4)陰影聴取や遮蔽雑音を考虑する必要がない，など多 くの利点があるからである゙12。

今回の26名の症例中，蝸電図，ERA 其化無反芯であ ったものは2例でちった. Lyons 等 $(1974)^{21)}$ む ERA と螖電図を併施し，22例の retardate のうち9例が deaf であったと述へている. 一方 Aran (1971) は29例の 幼愳に蝸電図を行い，9例が無反応であったが，そのう ちの3 例は低音の刺激に対して聴性行動反応を認めたと している.

2. 反応域值について 表 5 K示した樣に, 蝸電図 AP 反応域值は純音聴力損 
失值に較へ， $8 \mathrm{kHz}$ では $2.7 \mathrm{~dB}$ 上昇し， $4 \mathrm{kHz}$ では $2.9 \mathrm{~dB}$ 上昇し, $2 \mathrm{kHz}$ で $8.3 \mathrm{~dB}$ 上昇していた. し かし検討した例は突発難㯖例で $\mathrm{C}_{4}$-dip や $\mathrm{C}_{5}$-dip など の聴力像を示した者がなかったので，この様な症例であ 椧討する必要が残っている。

蝸笪図 AP 反忘域值と聴力損失值との関連については 多くの者が検討している. 吉江 $(1973)^{52)}$ は、クリック の自敩域值と反心域值の差は平均 $0.2 \mathrm{~dB}$ 飞すぎない して和り, tone pip の自営域値と反応域値の差む $7 \mathrm{~dB}$ 以内であると述べ，蝸電図が他党的悖力椧疽として充分 に役立つであううことを示唆している．他方，Davis （1973）は，蝎電四の AP は聴党域值の检㚗飞は役立た ないと述へているが(6)，Portmann"29， Elberling" Cullen ${ }^{4)}, H^{\prime}$ ooper ${ }^{12)}$, Tyberghein ${ }^{44)}$, など多くの者が 指摘する様に $1,500 \mathrm{~Hz}$ 以上の高調音についてはある程 度の周波数特異性があって，純音聴力損失值と比軨的一 致するというのが実際の様である。

上記のことから，26名の蝸電困施行者の聴力像を分類 したのが表 2 であったが，これは29例てついて検討した $\operatorname{Aran}^{1)}$ の報告と似ている．彼の資料では，9例が無反 忘，4例が異常反応， $60 \sim 90 \mathrm{~dB}$ のものが 7 例， $0 \sim 30$ $\mathrm{dB}$ のあが 6 例であった.

\section{3. 反応潜時}

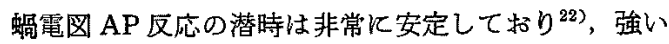
音では標準偳差值は小さくなってくる.これまでの報告 の大部分が，強い音では $1.2 \sim 1.5 \mathrm{msec}$ の範囲飞入って いる. 潜時と年令の関係化ついては, Liebermann ${ }^{19)}$ 方 年令が幼いと潜㭙は多少延長すると報告し，また Aran 2)が域值付近の音では成人の方が潜時が延長すると報告 している. 図 4 ，図 5 亿示した資料でも同様の傾向は認 められて括り，潜時の決定が (1) Travelling-time delay (2) Neural delay ${ }^{40)}$ (3) 基底膜の変位の大きさ ${ }^{45)}$ ，など によって行われるとすれば，これらの部分での末発達が 幼肾での潜時の延長をおこしているものと考えたい：ま た $4 \mathrm{kHz}$ の音沉対する潜時が，8 $\mathrm{kHz}$ に対する潜時飞 胶へ延長しているのは，媧牛での応答部位が $4 \mathrm{kHz}$ で はより尖端部にあることから考えて当然の結果である。

潜時の詳細な検討で，伝音難恥，混合難恥，感音難桼

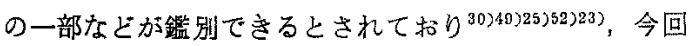
の26名の症例の中にも，潜時の延長之副耳の存在加伝 音嚾聴を疑った症例があった．裴 6 及び裴 7 亿示した様 飞正常児と難聴夰とで有意の差がないのは，難德の原因 が殆ど大部分感音難聴であるためと考えられる。

\section{AP 反応の振巾}

AP 反応の振巾恬，基總加らピークまでの高さを测る あのと ${ }^{48)}$, peak to peak を测定する者とがあるが》, 今回は基線からピーク克での高さを求めた. 吉江 ${ }^{4 a)}$,

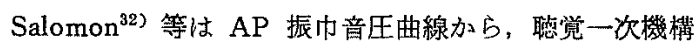
K2つの感覚単位が存在することを指摘したが, 幼児に ついても $\mathrm{H}$ 曲線及び L 劰線の二曲線が認められ，聴覚 一次機構に括ける機能の分化は既に成人と同様になって いることを示している.

\section{L 反応について}

L反心を゙ょこす部位はまだ明確ではないが，外有毛細 胞系の反応であると考えられている ${ }^{19)}$.ところでこの外 有毛細胞系と内有毛細胞系との間には Servomechanism 的な抑制機粠があると言われ20)35)，その結果強音ては L 反応が㧕制されると考えるのが妥当である. 図8に示し た例は強音飞てあ，反応が認められて招り，これは高 次な神経活動の異常が蝸電図 AP 波型上の変化として琵 われたと考光たい。

\section{SP 様電位について}

蝸霆図法で SP がとれるのは事実らしいが16)50)8)7741, その意義についてはまだ不明確である。図11亿は，経過 のよくわかっている成人のメ二エル病患者の蝸電図記録 が示してあり，著明な＋SPを示している，この症例は メニエル病の為飞正円空に食塩結晶を置く所謂 Arslan の手術を受けて扣り，術後喯力が少々悪化している時に 行われた螖電図記録である。その他, 变動する聴力障害 例で SP 様電位を認めている例向あり，SP は蛸牛の機 能異常を示唆するものと考兄られる53.，小児では，成人 の栚に詳しい病歷や症状の把挃ができないので，小児に 括ける SP の意嶬は一層不明確である。

\section{$V$ 結 果 一BSR -}

BSR を施行した41名の聴力像は，表11 K示した通り

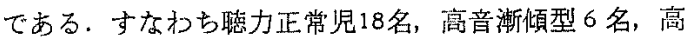

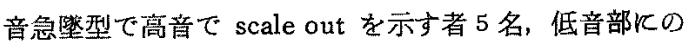
み残复のある者 5 名，全てに反応なし 7 名となった。

\section{1. 反応の有盽}

BSR 反忘群の中で，再現性のある ${ }^{18)} W_{5}$ の有㴆と ERA の反応の有無との関係を装12亿示した. 蝸電図の 場合之同様儿，ERAの方方度芯検出率が良い，BSRで 反応を認めず，ERAで反空の得られた者が 6 例あある のに対して，BSR で反応が得られたにも拘らず ERA で反応のなかった者は1例をすきない。こ一例は右耳 に高度の難聴のあることがわかって招り，右耳について 

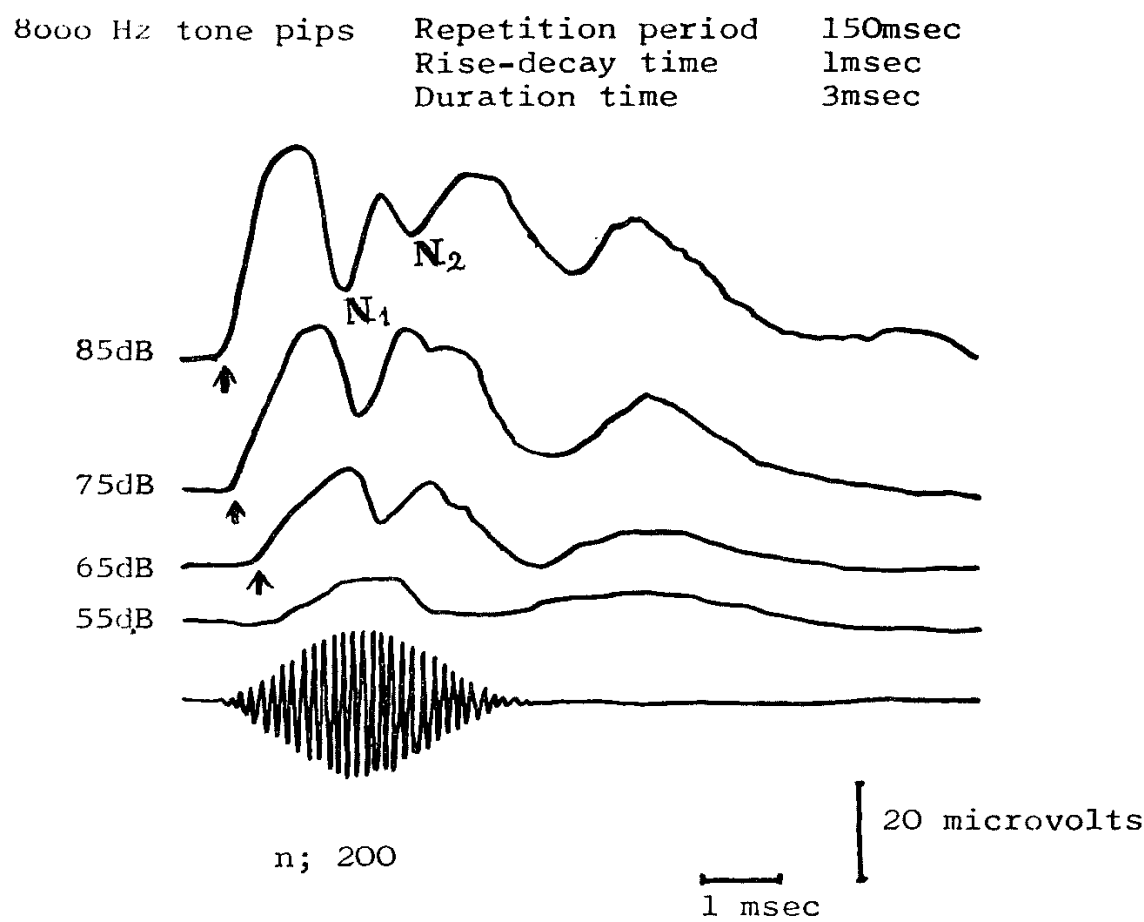

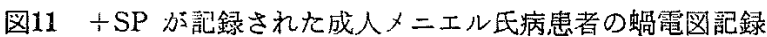

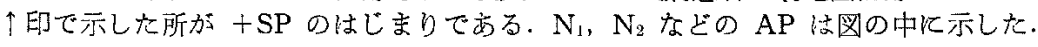

表11 BSR 施行例 (41名) の聴力

\begin{tabular}{|c|c|c|c|}
\hline ほ & $ほ$ & 正堂 & 18 名 \\
\hline 霓 & 音 & 漸 傾 & 6 名 \\
\hline 高 & 音 & Scale out & 5 名 \\
\hline 低 & 音 & 残 聴 & 5 名 \\
\hline 全 & 音 & Scale out & 7 名 \\
\hline
\end{tabular}

表12 ERA 及び BSR-W5 の反心検出率

\begin{tabular}{l|c|c|c}
\hline & $\begin{array}{c}\text { BSR-W5 } \\
\text { 反応市b }\end{array}$ & $\begin{array}{c}\text { BSR-W5 } \\
\text { 反応なし }\end{array}$ & \\
\hline ERA 反応あり & 20 名 & 6 名 & $76 \%$ \\
ERA 反応なし & 1 名 & 7 名 & $24 \%$ \\
\hline & $62 \%$ & $38 \%$ & \\
\hline
\end{tabular}

表13 ERA 反灾域傅と BSR-W 5 反応域熼との差

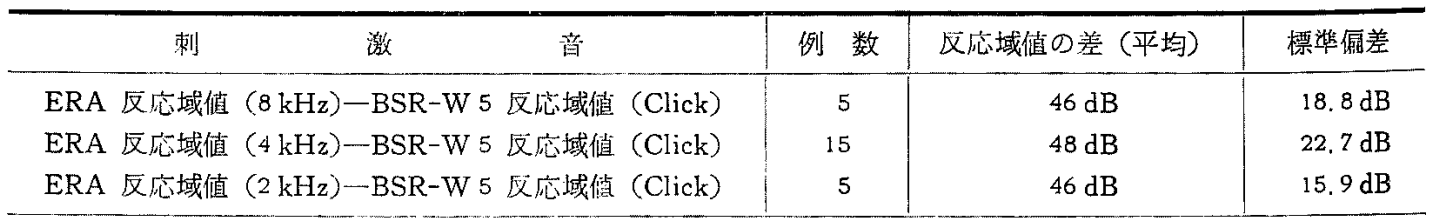

施行した ERA と、雨耳聴でしか行えないBSR とを比 校した例であった。

2. 反応域値一ERA 上 BSR の比软一

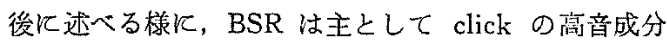
K対して得られるので, $2 \mathrm{kHz}, 4 \mathrm{kHz}, 8 \mathrm{kHz}$ の各 Tone burst 飞対するERA 反応域值と, click 飞対する BSR-
$W_{5}$ 反心域值との差てついて検討した（裴13）：この表 に示したのは差の平均と標準偏差であるが，ERA の反 応域值は少なくと毛 click 亿対する BSR 反応域值より 6 $25 \mathrm{~dB}$ 以上上景しているといえる。図 12 飞は全例の ERA と BSR の反心域偡が示してあるが， BSR で反 応が得られなかったにす拘占ず ERA（2 kHz，4 kHz， 


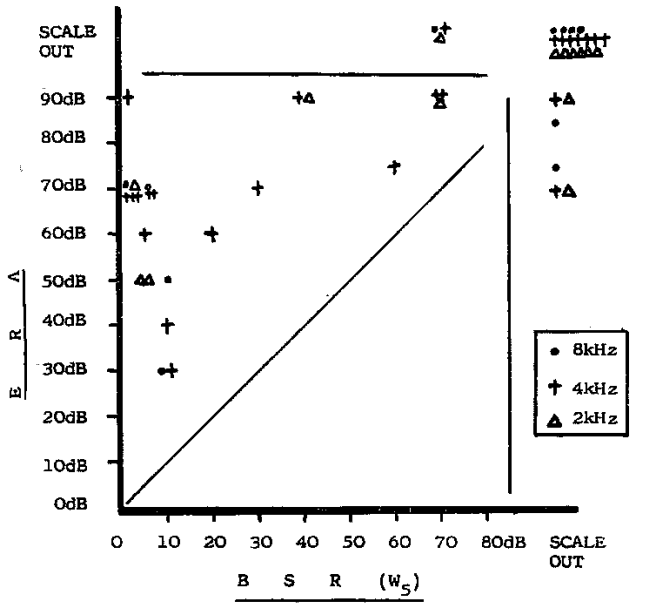

図12 ERA と BSR-W 5 の反応域值

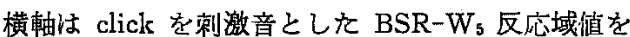
示し，䌅軸は tone burst を刺激音とした ERA 反 応域值を示す。

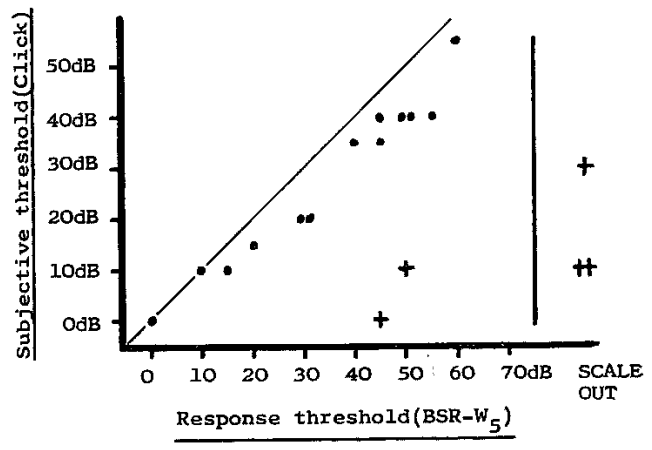

図13 Click 自覚域值と BSR-W 5 反応域值 横軸は BSR-W 反応域值を示し，緃軸は Click 自 覚域值を示す。，印は $2 \mathrm{kHz}$ 以上の高音急坆型難 璤を示す例である。

$8 \mathrm{kHz}$ ) で反応の得られた例が 2 名ある。この様な例が 存在することは考えにくく，この原因は (1) ERA での 波型判定に問題がある (2) BSR の剌激音は $70 \mathrm{~dB}$ まで しか出せない，の二点に占りそうである。

3. 自觉域值と BSR 反応域值

BSR 加他喾的聴力検查として役立つかはまだ明確で はない，そこで標蕉純音聴力桧亘を行い得た例で，BSR 反応域値やClick 自觉域値なととの関係を検討した.

因13k注 Click 自敩域值之 BSR 反応域值之の関係 が示してあり，十印で示した例は全て $2 \mathrm{kHz}$ 以上で高 音急壁型㯖力像を示す者である。この様な聴力像を呈す

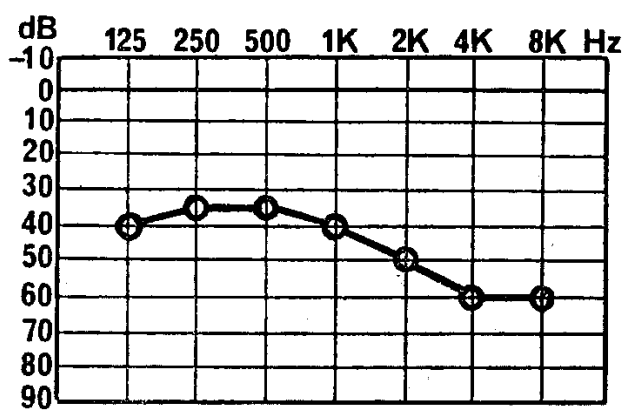

図14比較的水平な咕力損失を示す症例の聴力像 この症例の Click 自覚域值は $40 \mathrm{~dB}$ BSR 反応域値は $50 \mathrm{~dB}$

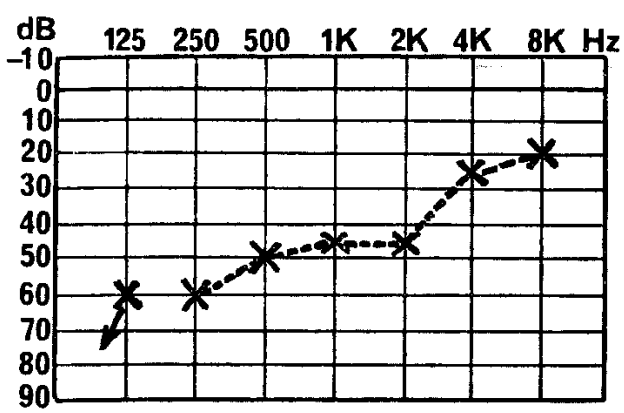

図15 低音障害型聴力損失を示す症例の聴力像 この症例の Click 自賞域值は $20 \mathrm{~dB}$ BSR 反応域值は $30 \mathrm{~dB}$

る者では Click 自覚域值上 BSR 反応域值とは大きな 差を示すが，一般には Click 自觉域值は BSR反応域值 より常袄く，その差の平均は $9.4 \mathrm{~dB}$ で, 標準偏差は $5.7 \mathrm{~dB}$ であった $(\mathrm{N}=18)$.

俧力像と BSR の反応域值については 图14〜因17 示す. 図14は平坦な聴力損失を示す例，図15は低音障害 型，図16は高音念型型，図17は中音域障害型の各例であ り，因の説明中に示した BSR 反応域值は高音域の聴力 損失值により関係がありそうだと推察でさる.今回オー ジオグラムの得られた20名について BSR 反応域值と聴 力損失倠之の関係を高音域，低音域にわりて検討し䘚 14 に示した. 亦なわち $2 \mathrm{kHz}, 4 \mathrm{kHz}$ の純音兒覚域值のう ちの低い方の值と BSR 反心域值との差を求め高音域と し, 他方 $250 \mathrm{~Hz}, 500 \mathrm{~Hz}$ の純音自党域值のうちの低い 方の值と BSR 反応域值との差を求め低音域とした.こ の結果から高音域の骤準痛差と低音域の標準偠差とは 1 $\%$ 危除部で有意の差があり，BSR 反忘域值は高音域と より関係が深いと言える。 


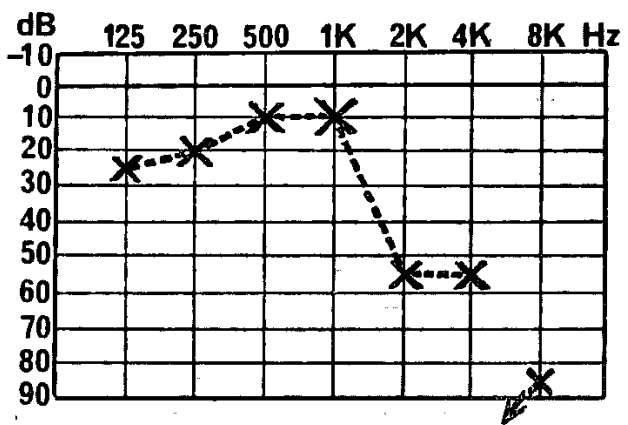

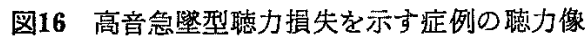
この症例の Click 自敩域值は $30 \mathrm{~dB}$ BSR 反応域偡は scale out

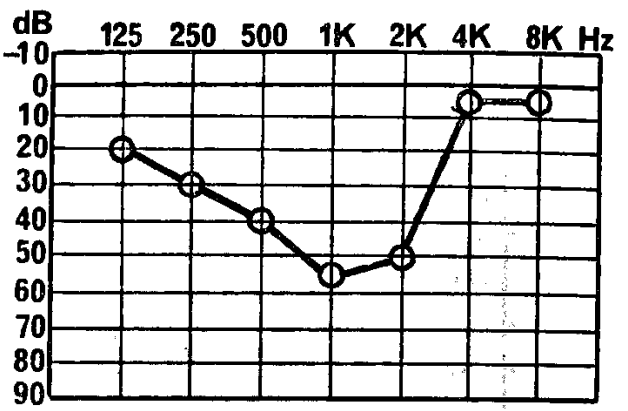

図17 中音域障害型聴力損失を示す症例の聴力像 この症例の Click 自営域值は不明 BSR 反心域値 $20 \mathrm{~dB}$

表14 純音聴力損失值と BSR-W 5 反応域値との差

\begin{tabular}{l|c|c|c}
\hline & 例 数 & 差 (平均) & 標準偏差 \\
\hline BSR 反応域值 (Click)一䋘音聴力域值 $(2 \mathrm{kHz}$ or $4 \mathrm{kHz})$ & 20 & $3 \mathrm{~dB}$ & $11.0 \mathrm{~dB}$ \\
BSR 反応域值 (Click)一純音聴力域值 $(250 \mathrm{~Hz}$ or $500 \mathrm{~Hz})$ & 20 & $5.3 \mathrm{~dB}$ & $20.6 \mathrm{~dB}$ \\
\hline
\end{tabular}

\section{4. 反忘潜時}

聴力正常児と突発觀聴成人の資料を対比させ衣15及び 図18K示した．音が弱くなるにつれ潜時は延長し，BSR - $W_{1}$ 反応の潜時は中等度音压飞於て急激に延長して招 り，蝸電図 AP反応の潜時と極めて似た特長を持ってい る.これらの潜時を検討した結果 (1)BSR-W 1 潜封の偏 差と蝸電図 AP 潜時の偏差とは 10\%危险率で有意の差 (2)Click による BSR-W 1 潜時は, tone pip による蝸電 因 AP 潜時より短い (3)正常児では $W_{1}$ 潜時の偏差と $W_{5}$ 潜時の偏差とは $5 \%$ 危険率で有意の差 (4)強音での $\mathrm{W}_{5}$ 潜時は成人と聴力正常児とは $5 \sim 10 \%$ の危険率で有 意の差がある。などの結論を得た ${ }^{38)}$.
$\mathrm{W}_{1}$ と $\mathrm{W}_{5}$ の間の peak interval の剆定を行ってみ た. それはシナプスや神経伀導の状態を示高良い指標と 思われたからである. 聴力正常児では，平均 $4.73 \mathrm{msec}$

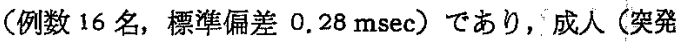
難聴) では平均 $4.57 \mathrm{msec}$ (例数 12 名, 標準偏差 0.32 msec)であった．これらを検定したが有意す差があると は言えながった。

\section{BSR-W 5 振巾}

聴力正常児の $\mathrm{W}_{5}$ 振巾は，強音では $1.18 \mu \mathrm{V} \sim 4.31$ $\mu \mathrm{V}$ の筑囲飞あり，その平均は $2.05 \mu \mathrm{V}(\mathrm{N}=16)$ であ った。他方難聴児の $\mathrm{W}_{5}$ 振巾は $0.37 \mu \mathrm{V} \sim 1.52 \mu \mathrm{V} の$

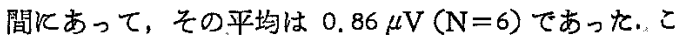

表15 聴力正常児の W 1, W 5 潜時と突発難聴成人の BSR-W 5 潜時

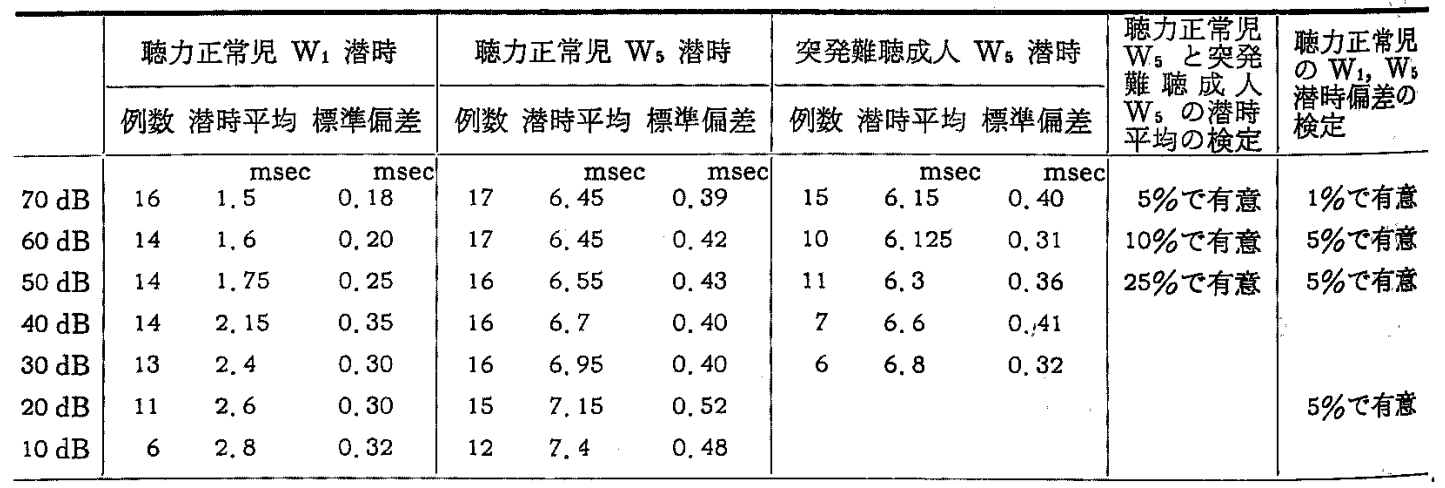




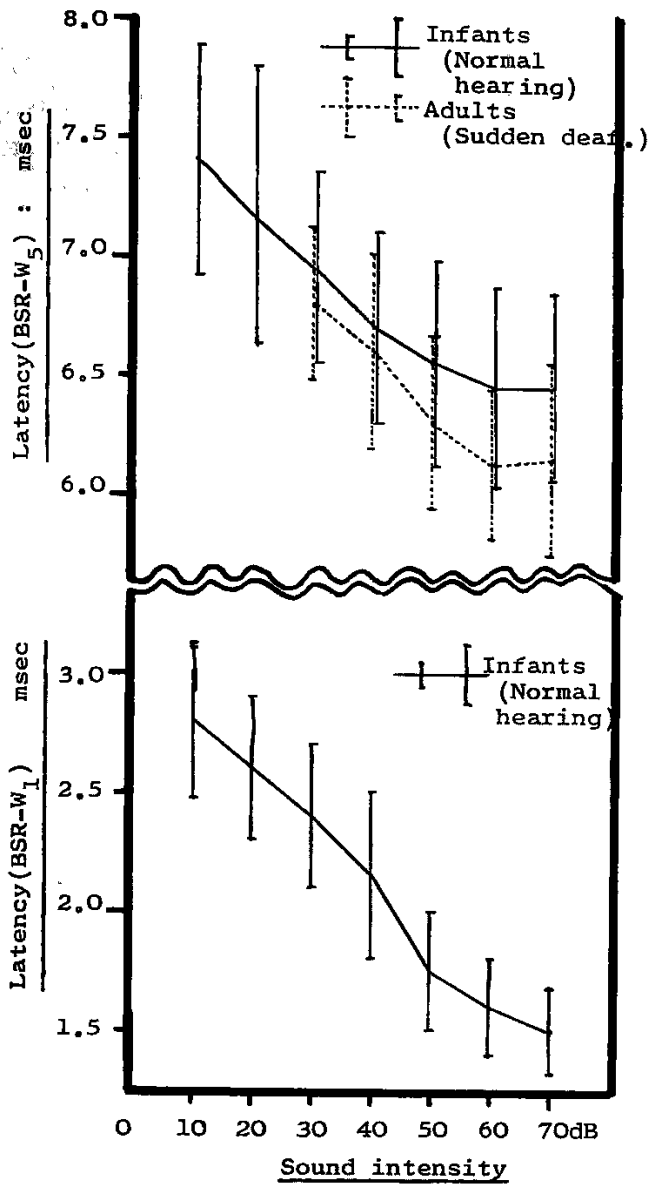

图18 BSR-W 18 及び BSR-W 5 の潜時音王曲線 $\mathrm{BSR}-\mathrm{W}_{1}$ 潜時は聴力正常児の資料のみであり, BSR $-W_{5}$ 潜時は聴力正常児の資料 $(-)$ と突発難聴成 人の資料 $(\cdots \cdots)$ とについて検討してある.

の様に W 5 振巾は非常に小さく，これを詳細に検討する 飞は測定誤差が大きくなってしまう．表16，図19亿，聴 力正常児13名の資料を示したが，標準偏差が非常に大き
表16 聴力正常児の BSR-W 5 振巾之 音の強さの関係（\% Maximum）

\begin{tabular}{r|ccl}
\hline & 例 数 & 平 均 & 標凖偏差 \\
\hline $70 \mathrm{~dB}$ & 13 & $100 \%$ & 0 \\
$60 \mathrm{~dB}$ & 13 & 78.3 & $14.48 \%$ \\
$50 \mathrm{~dB}$ & 13 & 69.6 & 17.38 \\
$40 \mathrm{~dB}$ & 13 & 62.8 & 17.74 \\
$30 \mathrm{~dB}$ & 13 & 53.3 & 17.02 \\
$20 \mathrm{~dB}$ & 12 & 42.1 & 16.61 \\
$10 \mathrm{~dB}$ & 9 & 34.2 & 10.20 \\
$0 \mathrm{~dB}$ & 6 & 19.9 & 6.56 \\
\hline
\end{tabular}

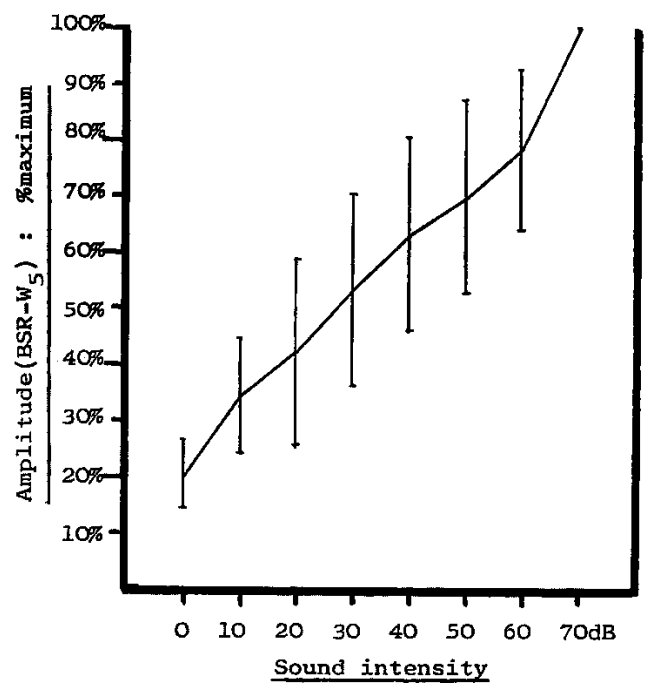

図19 BSR-W 5 の振幅音王曲線(聴力正常児の資料) 横軸は音の強さを示し, 縦軸は BSR-W 5 反応の振 幅を\% Maximum で表示した. 縦にひいた線は標 準偏差を示す

く，蝸電図 AP の様な細かい情報を得るとは不適当な指 標である.

難聴児の BSR の替時や振巾については表17に示した

表17 難聴児の BSR ( $W_{1}$ 潜時， $W_{5}$ 潜時，W $W_{5}$ 振巾（\% Maximum)）

\begin{tabular}{|c|c|c|c|c|c|c|c|c|c|c|c|c|}
\hline \multirow{2}{*}{ 音の強さ } & \multicolumn{2}{|c|}{$W_{l}$} & \multirow{2}{*}{$\begin{array}{l}\text { 潜 } \\
\text { 最小值 }\end{array}$} & \multirow{2}{*}{$\frac{\text { 時 }}{\text { 最大值 }}$} & \multicolumn{2}{|r|}{$W_{5}$} & 潜 & \multirow{2}{*}{$\frac{\text { 時 }}{\text { 最大值 }}$} & \multicolumn{2}{|r|}{$W_{5}$} & \multirow{2}{*}{$\frac{\text { 振 }}{\text { 最小值 }}$} & \multirow{2}{*}{$\frac{\text { 巾 }}{\text { 最大值 }}$} \\
\hline & 例 & 数 & & & 例 & 数 & 罗小值 & & 例 & 数 & & \\
\hline $70 \mathrm{~dB}$ & & 6 & $1.5 \mathrm{msec}$ & $1.9 \mathrm{msec}$ & & 6 & $5.75 \mathrm{msec}$ & 7. $1 \mathrm{msec}$ & & 5 & $100 \%$ & $100 \%$ \\
\hline $60 \mathrm{~dB}$ & & 6 & 1.5 & 2.25 & & 5 & 5.75 & 7.0 & & 4 & 75.0 & 87.5 \\
\hline $50 \mathrm{~dB}$ & & 4 & 2.0 & 2.45 & & 5 & 6.0 & 7.1 & & 5 & 54.5 & 87.5 \\
\hline $40 \mathrm{~dB}$ & & 4 & 2.25 & 2.75 & & 4 & 6.5 & 7.5 & & 4 & 41.4 & 62.5 \\
\hline $30 \mathrm{~dB}$ & & & & & & 3 & 7.1 & 7.75 & & 3 & 31.2 & 74.9 \\
\hline
\end{tabular}


が，「バラツキ」が大きく特別の傾向を見出し得なかっ た.

\section{1. 反応の有無}

\section{V 考. 察 $-\mathrm{BSR}-$}

Click 音のみで刺激する BSR と, 各周波数の tone burst で刺激する ERA とを比较すれば，明きらかに ERA の方が㭘查にひっかかってくる可能性が高い，同 一刺激により ERA と BSR を比較した報告は, 古賀 17), Sohmer ${ }^{342}$ のむのがある. Sohmer Kよれば, 再現 性, 反応域值などの点で BSR の方が龸れていると述べ ている. 他方, 古賀は, 反応域值という点では ERA, BSR 飞差がないが， Click が広い周波数分散を持つに あ拘らず Click による ERA では低音の反応洦られ ないと述へている. 一方, ERA は高調音 Tone burst では反応が得られにくい傾向があり，ERA では刺激音 として低音域の Tone burst が是非必要となってくる.

2. 反応の潜時

反応の潜時や波形は記録系に入っているフィルターの 影響をかなり受けるので，各報告者の資料を比較するに は注意を要する。

BSR-W 1 の潜時は蝸電図 AP の湻時と一致すると言 われているが，実際には BSR-W 1 潜時の方が標準偏差 值が大きい，蝸電図では AP 潜時を用いて難聴の鑑別診 断ができるとされているが， BSR-W 1 潜時を検討して も鑑別診断できる可能性はより少ないと言える．域值付 近まで反応の残る BSR-W 5 の潜時を用いた場合飞は標 準偏差は更に大きくなり，鑑別診断の指標として W 5 潜 時を使うのは不適当であると言える.

$\mathrm{W}_{1} \sim \mathrm{W}_{5}$ の潜時は年令が少ない程延長している 11)1331138)。潜時が成人の值に達するのは, Hecox ${ }^{11}$ によ れぼ12〜18ケ月, Rudolph ${ }^{31)}$ によれば2才, 堀内 ${ }^{13)}$ に よれぼ 2 才ケ月以後, などと言われているが, 実際に はもう少し遅いのではないかと考えられる(表15参照). $\mathrm{W}_{1}, \mathrm{~W}_{2}$ の潜時が成人の值飞達与るのが， $\mathrm{W}_{3}, \mathrm{~W}_{4}$ の 潜時が成人の值飞達するより早い之言われ ${ }^{15)}$, Myelination の䐅れが任導時間の遅れとなって表われていると考 えられる。

神経系の成熟度 (Myelination) の程度を判断する上に は， $W_{1} \sim W_{5}$ の間のピーク間隔の湘定をすることが意 味あると考えている.ピーク間隔については, Terkild$\operatorname{sen}^{41)}$ が $\mathrm{N}_{1} \sim \mathrm{N}_{2} 0.9 \mathrm{msec}, \mathrm{N}_{2} \sim \mathrm{N}_{3} 1.1 \mathrm{msec}, \mathrm{N}_{3} \sim$ $\mathrm{N}_{4} 1.6 \mathrm{msec}, \mathrm{N}_{4} \sim \mathrm{N}_{5} 1.5 \mathrm{msec}$ ，(従って $N_{1} \sim N_{5}$ 間

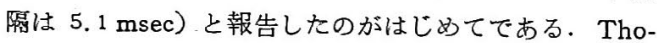

rnton $^{42)}$ は, 多発性硬化症では $\mathrm{N}_{1}$ 潜時は正常だが, $\mathrm{N}_{2}$ 以後の潜時が遅れ巾の広い平坦な波形となると述へてい る. $W_{1} \sim W_{5}$ 間隔は音圧の影響を受けないとされてお

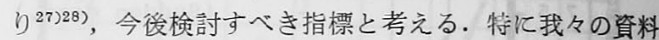
から考えて $5 \mathrm{msec}$ 以上の長さを持つ $\mathrm{W}_{1}-\mathrm{W}_{5}$ 間隔は 異常と考えて良いと思われる。

3. BSR-W 5 振巾

$W_{5}$ の波形飞は Slow response ${ }^{39)}$ が重なっている為 に,その振巾の測定には困難が多い.その他に低周波の高 振巾の雑音も混入しやすく ${ }^{36)}$ ，基線から negative peak までの測定をもって振巾とするには疑問が多い.むしろ Terkildsen $^{41)}$, Thornton ${ }^{43)}$ などの様に, Negative peak から次の Positive peak までの peak to peak ですっ て振幅を測定するのが良いと思われる．この様な方法で 测定しても図19亿示方様漂準偏差值が非常に大きく検 討に值しないというべきである.

$$
\text { VII 結論 }
$$

1. 螖電図

i）反応検出率は ERA の方が蝸電図より高い。

ii） 区応域値は蝸電図の方か ERA より低い。

iii）蝸電図 AP 反応域值は, $2 \mathrm{kHz}, 4 \mathrm{kHz}, 8 \mathrm{kHz}$ の高調音に対しては純音自覚域值と比較的近い值を とる.

iv） AP 潜時は，聴力正常児と突発難聴成人との間て 有意の差がある。

v）強音での AP 振幅は，聴力正常児と難聴児の間で 差があり，難聴児の方が小さい.

vi）正常児では，AP 振幅音圧曲線は $\mathrm{H}$ 曲線と L曲 線で構成されている.

vii）強い音では SP が記録されることがある．

viii）強い音でも L 反応の残っている例があり，こ れは神経系の異常を示唆するすのと考えられる.

2. BSR

i）反応検出率は ERA の方が BSR より高い。

ii）高音域に於ける ERA 反心域值は，Clickによる BSR 反応域值より $25 \mathrm{~dB}$ 以上上昇している.

iii) Click 自営域值と BSR 反忘域值とは比較的近い 值をとる. 但し $2 \mathrm{kHz}$ 以上の高音急慜型難聴を示 す者では大きな差が生ずる。

iv） BSR 反応域值は，高音域に括ける純音聴力損失 值とより樑い関係がある。

v) BSR-W 1 潜時は蝸電図 AP 潜時にくらべ標準偏 差が大きい、 $W_{5}$ 潜時となると標準偏差值は更に大 
きくなる．従って BSR の反応潜時であって鑑别診 断を行うことは危険が大きい。

vi) BSR-W 5 潜時は成人と幼児とでは異なる.

vii） $\mathrm{W}_{1} \sim \mathrm{W}_{5}$ までのピーク間隔は成人と幼览では差 がないという仮説を否定できなかった。

viii） Ws 振幅音圧曲線は標準偏差が大きく，蝸電図 $\mathrm{AP}$ 振蝠音正曲線の様にパターンとして把え分析す ることは不可能である.

\section{参考 文 献}

1) Aran, J.M.: The Electrochleogram: Recent Results in Children and in some Pathological Cases. Arch. klin. exp. Ohr.-Nas.-u. Kehlk., Heilk. 198 : 128-141, 1971.

2) Aran, J.M.: Clinical Measures of VIIIth Nerve Function. Adv. Oto-Rhino-Laryng., $20: 374-394$, 1973.

3) Beagley, H.A.: Can we use the cochlear microphonic in electrocochleography? Rev. Laryng., $95: 531-536,1974$.

4) Cullen, J.K., el al.: Human Acoustic Nerve Action Potential Recording from the Tympanic Membrane without Anesthesia. Acta Otolaryng.$74: 15-22,1972$.

5) Davis, H.: Sedation of Young Children for Electric Response Audiometry (ERA): Summary of a Symposium. Audiology, 12:55-57, 1973.

6) Davis, H.: Classes of Auditory Evoked Responses. Audiology, $12: 464-469,1973$.

7) Eggermont, J.J.: Basic principles for electrocochleography. Acta Otolaryng., Suppl. 316:716, 1974.

8) Eggermont, J.J. and Odenthal, D.W.: Action potentials and summating potentials in the normal human cochlea. Acta Otolaryng., Suppl. 316: 39-61, 1974.

9) Elberling, C. E Salomon, G.: Electrical Potentials from the Inner Ear in Man in Response to Transient Sounds Generated in a Closed Acoustic System. Rev. Laryng., 92 : 691-706, 1971.

10) Gerull, G. et al.: Properties of an early AER of 5-10 ms Latency. Rev. Laryng., 95 : 560-565, 1974.
11) Hecox, $K$. et al.: Brain Stem Auditory Evoked Responses in Human Infants and Adults. Arch. Otolaryng. $99: 30-33,1974$.

12) Hooper, R.: Electrochleography. J. Laryng., $87: 919-927,1973$.

13）堀内潔子：聴性脑幹反応と乞の臨床応用火関寸る研 穴. 日耳鼻，78：807-819，1975（昭 50).

14) Jervett, D.L. \& Williston, J.S.: Auditoryevoked far fields averaged from the scalp of humans. Brain, $94: 681-696,1971$.

15) Jewett, D.L. छ Romano, M.N.: Neonatal development of auditory system potentials averaged from the scalp of rat and cat. Brain Research, $36: 101-115,1972$.

16) Kiang, N.Y-S. \& Peake, W.T.: Components of electrical responses recorded from the cochlea. Ann. Otol., 69 : 448-458, 1960.

17）古賀度次郎他：幼児聴力湘定法としての聴性脳幹反 応（BSR）飞脑波誘発反応（ERA）の関係汇ついて。 Audiology (Japan), $18: 318-326,1975$.

18）小泉 智: 幼児睡眠時の聴性脑幹反応の恒常性につ Wて。 日耳奥, $78: 820-825,1975$.

19) Lieberman, A. F Sohmer, H.: Standard Values of Amplitude and Latency of Cochlear Audiometry (Electro-cochleography). Responses in Different Age Groups. Arch. klin. exp. Ohr.-Nas.-u. Kehlk. Heilk., 203 : 267-273, 1973.

20) Lynn, P.A. \& Sayers, B. McA.: Cochlear Innervation, Signal Processing, and their Relation to Auditory Time-Intensity Effects. J. Acoust. Soc. Am., 47 : 525-533, 1970.

21) Lyons, G.D. et al.: Electrochleography with retardates. Laryngoscope, $84: 990-997,1974$.

22) Montandon, P.B., et al.: Recording auditorynerve potentials as an office procedure. Ann. Otol., $84: 2-10,1975$.

23) Odenthol, D.W. E Eggermont, J.J.: Clinical electrocochleography. Acta Otolaryng., Suppl. $316: 62-74,1974$.

24) Odenthal, D.W. et al.: Diagnosis by electrocochleography. Rev. Laryng., 95 : 481-488, 1974.

25）大橋 徹: 感音系難聴耳（特飞 Sensory neural defects）に於ける蝸牛神経活動電位。日耳番， $72 ：$ 
1269-1287，1969.(昭 44).

26) 大西信治郎他：庶眠時 ERA の波形判定基淘 (1).

Audiology (Japan), 18 : 189-194, 1975.

27) 大西信治郎他: Rise time, Duration $の B S R へ の$

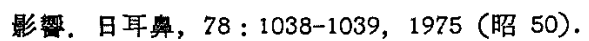

28) Picton, T.W. et al.: Human auditory evoked potentials. I. Evaluation of components. Electroenceph. clin. Neurophysiol., 36:179-190, 1974.

29) Portmann, M. \& Aran, J.M.: Electro-cochleography. Laryngoscope, 81 : 899-910, 1971.

30) Ruben, R.J. et al.: Cochlear potentials in man.

Laryngoscope, 71 : 1141-1164, 1961.

31) Rudolph, $N$. et al.: Clinical experience with an early AER of $5-10 \mathrm{~ms}$ Latency. Rev. Laryng. 95 : 566-570, 1974.

32) Salomon, G. \& Elberling, C.: Cochlear Nerve Potentials Recorded from the Ear Canal in Man. Acta. Otolaryng., 71 : 319-325, 1971.

33) Sohmer, H. et al.: Routine Use of Cochlear Audiometry in Infants with Uncertain Diagnosis. Ann. Otol., 81 : 72-75, 1972.

34) Sohmer, $H$. et al.: Electrocochleography or Evoked Cortical Responses: Which is Preferable in Diagnosis of Hearing Loss? Rev. Laryng., 95 : 515-521, 1974.

35) Spoendlin, H.: Degeneration Behavior of the Cochlear Nerve. Arch. klin. exp, Ohr.-Nas.-u. Kehlk. Heilk., 200 : 275-291, 1971.

36) Spreng, M. \& Keidel, W.D.: Problems of Simple Averaging of Electro-physiological Recordings and the Use of Additional Methods. Rev. Laryng., 92 : 722-738, 1971.

37) Suzuki, T.: Problems in Électric Response Audiometry (ERA) during Sedation. Audiology, $-12: 129-136,1973$.

38）鈴木篤郎他：㯖性譄幹反応と乞の他覚的聴力測定人 の応用。日耳围， $77: 587-592 ， 1974$ (昭 49)。

39.) 鈴木篤郎他: 聴性誘発反応の整理, 第23回中部地方 連合会, 昭和50年9月 7 日。

40) Tasaki, I. E Davis, H.: Electric responses of individual nerve elements in cochlear nucleus to sound stimulation (Guinea pig). J. Neurophysiol., $18: 151-158,1955$.

41) Terkildsen, $K .:$ Electrocochleography with a far field technique. Scand. Audiol.; 2 : 141-148, 1973.
42) Thornton, A.R.D.: The diagnostic potential of surface recorded electrocochleography. British J. Audiol., $9: 7-13,1975$."

43) Thornton, A.R.D.: The measurements of surface-recorded electrocochleographic responses. Scand. Audiol., 4 : 51-58, 1975.

44) Tyberghein, J.: Cochleography and recruitment. Rev. Laryng., 95 : 497-501, 1974.

45) Wang C-Y. \& Dallos, P.: Latency of WholeNerve Action Potentials: Influence of Hair Cell Normalcy. J. Acoust. Soc. Am., 52 : 1678-1686, 1972.

46）八木聡明他：幼小児難聴診断における Brain Stem Response の有用性について. Audiology (Japan). $18: 214-220,1975$ (昭 50).

47）吉江信夫他：ヒトの聴神経活動電位. 日耳番, 70 : 920-931， 1967 (昭 42).

48) Yoshie, N. et al.: Non-surgical of Auditory Nerve Action Potentials in Man. Laryngoscope, 77 : 76-85, 1967.

49) Yoshie, N.: Auditory Nerve Action Potential Responses to Clicks in Man. Laryngoscope, 78 : 198-215, 1968.

50) Yoshie, N. \& Ohashi, T.: Clinical Use of Cochlear Nerve Action Potential Responses in Man for Differential Diagnosis of Hearing Loss. Acta Otolaryng., Suppl. 252 : 71-87, 1969.

51) Yoshie, N.: Clinical Cochlear Response Audiometry by means of an Average Response Computer: Non-surgical Technique and Clinical Use. Rev. Laryng., 92 : 646-672, 1971.

52) Yoshie, N.: Diagnostic Significance of the Electrocochleogram in Clinical Audiometry. Audiology, 12 : 504-539, 1973.

53) Yoshie, N.: Electrocochleographic Classificatión of Sensorineural Defects: Pathological Pattern of the Cochlear Nerve Compound AP in Man. Electrocochleography Conference, June, 1974 (New York).

54) Zvonar, M. et al.: Anesthesis and sedation for electrocochleography. Acta Otolaryng., Suppl. $316: 37-38$, 1974.

稿を終るにあたり，御指導，御校閲下さつた恩師斉藤 成司教授飞心上り感謝致します。また，終始直接御指導 .下さつた国立小児病院耳咽续科部長古賀度次郎博士 （麿応大学諥師）に厚く御礼申乙上げます，また，本研 究飞着手するにあたり種々御助言下さつた信州大学吉江 信夫講師に謝意を表します。

なお，種ふ御協力いたたいた，神崎代講師をはじ度 応大学病院耳咽喉科聴営前庭研究班の諸先生に御礼申 しあげます。

（原稿受付 昭和 $51 ， 3.22$ 日急錙） 